\title{
Dune bedforms produced by dilute pyroclastic density currents from the August 2006 eruption of Tungurahua volcano, Ecuador
}

\author{
Guilhem Amin Douillet • Daniel Alejandro Pacheco • Ulrich Kueppers • \\ Jean Letort • Ève Tsang-Hin-Sun • Jorge Bustillos • Minard Hall • \\ Patricio Ramón • Donald B. Dingwell
}

Received: 17 February 2013 / Accepted: 17 September 2013 /Published online: 13 October 2013

(C) The Author(s) 2013. This article is published with open access at Springerlink.com

\begin{abstract}
A series of pyroclastic density currents were generated at Tungurahua volcano (Ecuador) during a period of heightened activity in August 2006. Dense pyroclastic flows were confined to valleys of the drainage network, while dilute pyroclastic density currents overflowed on interfluves where they deposited isolated bodies comprising dune bedforms of cross-stratified ash exposed on the surface. Here, the description, measurement, and classification of more than 300 dune bedforms are presented. Four types of dune bedforms are identified with respect to their shape, internal structure, and geometry (length, width, thickness, stoss and lee face angles, and stoss face length). (1) "Elongate dune bedforms" have smooth shapes and are longer (in the flow direction) than wide
\end{abstract}

Editorial responsibility: V. Manville

Electronic supplementary material The online version of this article (doi:10.1007/s00445-013-0762-x) contains supplementary material, which is available to authorized users.

G. A. Douillet $(\bowtie) \cdot U$. Kueppers $\cdot$ D. B. Dingwell

Earth \& Environmental Sciences, Ludwig-Maximilians-Universität (LMU), Munich, Germany

e-mail: g.douillet@min.uni-muenchen.de

D. A. Pacheco $\cdot$ J. Bustillos $・$ M. Hall $\cdot$ P. Ramón

Instituto Geofísico, Escuela Politécnica Nacional, Quito, Ecuador

J. Letort $\cdot$ È. Tsang-Hin-Sun

Ecole et Observatoire des Sciences de la Terre, Université de

Strasbourg, Strasbourg, France

J. Letort

Laboratoire de Géophysique Interne et Tectonophysique (LGIT), Grenoble, France

È. Tsang-Hin-Sun

Laboratoire de Géosciences Marines, Université de Brest, Brest, France or thick. Internal stratification consists of stoss-constructional, thick lensoidal layers of massive and coarse-grained material, alternating with bedsets of fine laminae that deposit continuously on both stoss and lee sides forming aggrading structures with upstream migration of the crests. (2) "Transverse dune bedforms" show linear crests perpendicular to the flow direction, with equivalent lengths and widths. Internally, these bedforms exhibit finely stratified bedsets of aggrading ash laminae with upstream crest migration. Steep truncations of the bedsets are visible on the stoss side only. (3) "Lunate dune bedforms" display a barchanoidal shape and have stratification patterns similar to those of the transverse ones. Finally, (4) "two-dimensional dune bedforms" are much wider than long, exhibit linear crests and are organized into trains. Elongate dune bedforms are found exclusively in proximal deposition zones. Transverse, lunate, and two-dimensional dune bedforms are found in distal ash bodies. The type of dune bedform developed varies spatially within an ash body, transverse dune bedforms occurring primarily at the onset of deposition zones, transitioning to lunate dune bedforms in intermediate zones, and two-dimensional dune bedforms exclusively on the lateral and distal edges of the deposits. The latter are also found where flows moved upslope. Elongate dune bedforms were deposited from flows with both granular-based and tractional flow boundaries that possessed high capacity and competence. They may have formed in a subcritical context by the blocking of material on the stoss side. We do not interpret them as antidune or "chute-and-pool" structures. The dimensions and cross-stratification patterns of transverse dune bedforms are interpreted as resulting from low competence currents with a significant deposition rate, but we rule out their interpretation as "antidunes". A similar conclusion holds for lunate dune bedforms, whose curved shape results from a sedimentation rate dependent on the thickness of the 
bedform. Finally, two-dimensional dune bedforms were formed where lateral transport exceeds longitudinal transport; i.e., in areas where currents were able to spread laterally in low velocity zones. We suggest that the aggrading ash bedsets with upstream crest migration were formed under subcritical flow conditions where the tractional bedload transport was less important than the simultaneous fallout from suspension. This produced differential draping with no further reworking. We propose the name "regressive climbing dunes" for structures produced by this process. A rapid decrease in current velocity, possibly triggered by hydraulic jumps affecting the entire parent flows, is inferred to explain their deposition. This process can in principle hold for any kind of particulate density current.

Keywords Pyroclastic dunebedforms $\cdot$ Antidune $\cdot$ Aggrading structures $\cdot$ Regressive climbing dunes $\cdot$ Tungurahua

\section{Introduction}

\section{Pyroclastic density currents}

Pyroclastic density currents (PDCs) are gas particle flows produced during explosive eruptions (Druitt 1996). They exhibit a wide range of particle concentration, grain size distribution, and temperature, and they vary in concentration gradient, flow density, and transport mechanisms (Sparks 1976; Burgisser and Bergantz 2002).

Pioneer authors classified PDCs into three end-members based on deposit characteristics: (1) flow (massive, unsorted, coarse-grained, and topography-confined deposits from "dense pyroclastic flows"), (2) surge (often cross-stratified, relatively sorted, finer grained, and topography-influenced deposits from laterally moving, low particle concentration "dilute PDCs"; Wohletz and Sheridan 1979; Walker 1984), and (3) fall (stratified or massive, sorted draping deposits from "fallout"). It has been emphasized that deposits mainly reflect basal boundary zone processes (Carey 1991; Branney and Kokelaar 1997), and a classification into granular, tractional, and direct falloutdominated boundary flows has been adopted by Branney and Kokelaar (2002, Chap. 4). Other classifications define two groups: inertia-dominated and gravitation-dominated flows (Doronzo 2012). All of these terms are relevant for aspects of this study but they only represent conceptual end-members. The different transport mechanisms are probably gradational in nature, and PDCs are likely continuously stratified flows with different types of particle support (Rowley et al. 1985; Valentine 1987; Burgisser and Bergantz 2002), that can evolve both in time and space (Wohletz and Sheridan 1979; Branney and Kokelaar 2002, Chap. 6; Sulpizio et al. 2008).

Here, we describe the dune bedforms and crossstratification patterns found in the deposits of dilute PDCs generated at Tungurahua volcano (Ecuador) in August 2006. The excellent preservation of the surface shape of the bedforms makes it a unique outcrop, enabling analysis of their spatial distribution and relationships with inferred current dynamics.

Dune bedforms in deposits of dilute PDCs

\section{Terminology}

We term dune bedforms (DBs) the decimeter- to decameterscale undulations on the surface of the deposits. We use this name in a purely descriptive way, following "bed form" as defined in Bridge and Demicco (2008, p. 157) as "a single geometric element, such as a ripple or a dune", as "dune form" was used in Mattson and Alvarez (1973). DB is equivalent to "sand-wave" (Wohletz and Sheridan 1979; Allen 1982; Sigurdsson et al. 1987; Cole 1991; Druitt 1992), a term avoided in this study because it is loosely defined (bedforms are not waves), and to prevent confusion with the term "sediment wave" (kilometer-scale undulations in turbidites; Wynn and Stow 2002). We avoid using simply "dune" since it has a genetic connotation (a dune is deposited from a subcritical flow across interaction with a flow-free boundary; Bridge and Demicco 2008, pp. 163 and 169). We use "length" to describe the distance from the onset to the end of the DB in a direction perpendicular to the crest (i.e., parallel to the flow direction) rather than "wavelength" that refers to the spacing between successive crests in repetitive trains of bedforms exclusively (conventional crest-to-crest wavelength; Fig. 1). "Thickness" is preferred to "amplitude", since the DBs potentially did not reach equilibrium before deposition ended. "Width" refers to the extent of the DB parallel to the crest. The stoss side faces upstream and the lee downstream (Fig. 1). Cross-stratifications are strata inclined with respect to an underlying plane bed and record the temporal evolution of a bedform (Fig. 2). "Lamina" refers to a millimeter-scale strata, "bedset" to a group of laminae that follow a common pattern and a "layer" represents

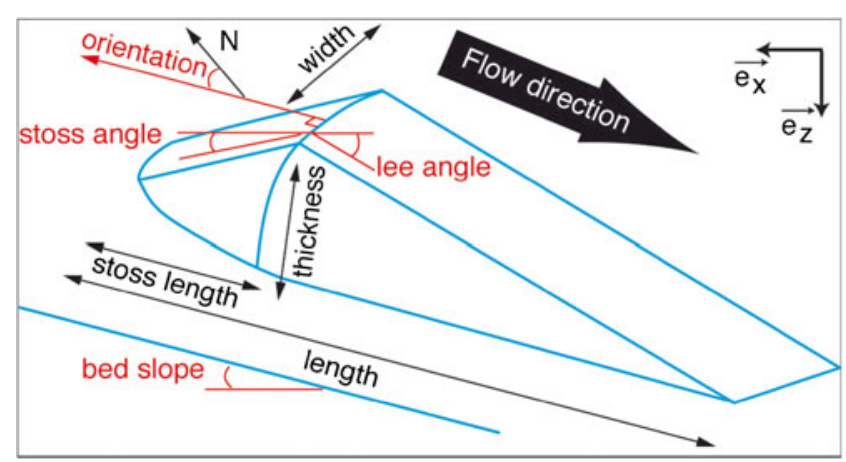

Fig. 1 Sketch of the measurements carried out on bedforms: stoss and lee face angles taken to the horizontal, width, crest orientation, stoss face length, length, and thickness of exposed bedform 
a single, thick $(>1 \mathrm{~cm})$ and massive strata. We speak of "constructional features" when part of the laminations are preserved so that a bedform partly "climbs" on its neighbour during migration (such as climbing or drift cross-laminations). "Aggrading features" is used when preservation occurs on both sides of the bedform so that individual strata can be followed from the stoss to the lee side across the crest, resulting in the complete expression of the original geometry of the bedforms. In that case, the crests of successive strata forming a DB can be shifted laterally with respect to each other, leading to upstream or downstream crest-migrating structures (also termed regressive and progressive, respectively). Note that up- or downstream migration of a crest should not be confused with migration of the whole structure. Indeed, in contrast to most fluvial and aeolian bedforms, there is no migration of the whole structure because accretion occurs on both sides of the bedform. "Stoss-aggradation" indicates that the stoss face is subjected to more aggradation than the lee, inducing upstream crest migration during growth of the bedform ("regressive"). "Formsets" are bedsets that have the overall shape of a bedform (Fig. 2).

\section{Interpretations}

Cross-stratification within PDC deposits was recognized as a primary feature from observations of DBs produced by nuclear test base surges and modern dilute PDCs (Moore et al. 1966; Moore 1967). DBs produced by dilute PDCs can exhibit: (1) very steep or very low face angles on both sides of a DB, (2) very common aggrading nature with up- or downstream migration of successive crests and appearance of cross-stratification within formsets, (3) successive individual laminae with heterogeneous grain size distributions, (4) steep truncations covered by stoss-aggrading lensoidal layers. Many interpretations and suggestions regarding the formation of PDC DBs have been put forward, as described below, but controversy remains.

\section{(a) Climbing dunes}

Aggrading cross-bedding (with both migration directions) is ubiquitous in the dilute PDC sedimentary record (Fig. 3 of Fisher and Waters (1969); Fig. 7 of Mattson and Alvarez (1973); types III and IV of Schmincke et al. (1973), Fisher (1977), Yokoyama and Tokunaga (1978),

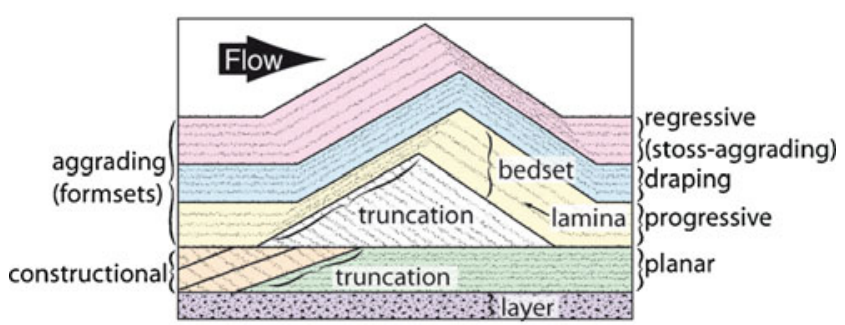

Fig. 2 Nomenclature for the different cross-stratification patterns. Colors refer to a group with similar characteristics
Wohletz and Sheridan (1979), Allen (1982, p. 425), and Sohn and Chough (1989); types A, B, C of Cole (1991) and Fig. 2 of Dellino et al. (2004)). These characteristics have often been described and/or interpreted as "climbing dunes" (Walker 1984; Sohn and Chough 1989; Cagnoli and Ulrich 2001). Note however that "climbing dune" is not a descriptive term for "aggrading DB" as it contains an intrinsic interpretation as "lower flow regime" bedform, as used by Sohn and Chough (1989). Climbing dunes form under high deposition rates (Allen 1970; Ghienne et al. 2010), as noted in the PDC environment by Walker (1984), who observed that "the environment in which climbing dune-bedded surge deposits form is a strongly depositional one: the surges were heavily laden, and as they slowed down they rapidly shed their load".

(b) Antidunes

According to fluid dynamics, antidunes are related to stationary gravity waves trapped at density interfaces (Prave 1990; Alexander et al. 2001). Gravity waves only form if there is a free-density interface that can oscillate (e.g., water and air (Alexander et al. 2001; Duller et al. 2007); a density current and an ambient fluid (Hand 1974; Spinewine et al. 2009)). For a gravity wave to become stationary over a bed, wave velocity must equal flow velocity, but in the opposite direction. This condition happens in the transcritical regime (Froude number close to 1; Guyon et al. 2001, p. 289; Duller et al. 2007).

In PDC sedimentology, "antidune" was initially used as a descriptive term for low-angle, meter-scale, crossstratifications inclined at angles less than the repose angle on both sides resembling standing waves (in fact, stationary waves!) with aggrading patterns, i.e., without a meaning in terms of fluid dynamics (Fisher and Waters 1969, 1970; Waters and Fisher 1971). Subsequent usage adopted the fluid dynamics connotation, thus turning into an interpretation (Crowe and Fisher 1973; Mattson and Alvarez 1973; Schmincke et al. 1973).

Confusion has since arisen and "antidune" has been variously used as (1) a descriptive term for DBs showing upstream crest migration, (2) DBs with aggrading bedsets, (3) low-angle cross-stratifications, or as (4) a fluid dynamics interpretation for different kinds of DB crossstratifications in PDCs (Fisher 1977; Yokoyama and Tokunaga 1978; Wohletz and Sheridan 1979; Walker et al. 1981; Fisher et al. 1983; Suthren 1985; Sohn and Chough 1989; Charland and Lajoie 1989; Gianneti and Luongo 1994; Brand and White 2007; Gençalioğlu-Kușcu et al. 2007; Brand et al. 2009; Brand and Clarke 2009, 2012; Kelfoun et al. 2009; Andrews and Manga 2012). Similarly, the term "chute and pool" has been variously used as an interpretative/descriptive term for stoss aggrading, lensoidal layers laying on steep truncations, 
even if "chute and pool" should exclusively be reserved as interpretation of deposits produced by hydraulic jumps (Schmincke et al. 1973).

(c) Basal boundary processes

In contrast to a structure fully ruled by the fluid-phase dynamics, it has been suggested that the formation of DBs was controlled by the basal flow-bed boundary (Branney and Kokelaar 2002, Chap. 4). Cohesive effects due to water content have been pointed to as a possible source for stoss-aggrading bedforms unrelated to gravity waves (e.g., Allen 1982, pp.428-429), but the observation that both up- and downstream migration occurs during single events excludes this (Cole 1991; Druitt 1992). Other types of distrainment effects (the opposite of entrainment) might however have an influence on the formation of DBs. Deposits are thus often interpreted in terms of a basal boundary zone (Branney and Kokelaar 2002, Chap. 4). Several studies suggested boundary zones intermediate between two end members. A tractional boundary that is inhibited by a high basal clast concentration is thought to account for fine-grained, massive or faintly stratified beds (Branney and Kokelaar 1997; Brown and Branney 2004; Sulpizio et al. 2010). Tractional and fallout boundaries are inferred for faint, low-angle cross-stratifications with fallout grain characteristics (Valentine and Giannetti 1995; Wilson and Hildreth 1998). Under water, "raining" sediment seems to inhibit cross-bedding development for antidunes but not lower stage bedforms (Arnott and Hand 1989), whereas a high fines concentration eases the formation of cross-lamination (Simons et al. 1963), and rapidly depositing suspensions from a density current produce poorly graded deposits (Sumner et al. 2008).

(d) Particulate density currents and pulsating nature

It is often hypothesized that dilute PDCs have pulsating behavior (Wohletz and Sheridan 1979; Valentine 1987; Sohn and Chough 1989; Sulpizio and Dellino 2008) and that this might trigger formation of stossaggrading bedforms unrelated to antidunes (Collela and Hiscott 1997; Vasquez and Ort 2006; Sulpizio et al. 2007; Sulpizio and Dellino 2008). Dilute pulses would lose their kinetic energy rapidly (Wohletz 1998), each pulse producing a single lamina or bedset by stepwise deposition (Walker 1984; Cole 1991; Sulpizio et al. 2007). Vasquez and Ort (2006) interpreted the succession of truncated bedsets and overlying capping sets as indication of waning flows with a leading head and slower tail. Stoss-aggrading structures are typical of the PDC record, but also widely observed in turbidites at the kilometer scale (Nakajima and Satoh 2001; Wynn and Stow 2002), the meter scale (Mulder et al. 2009; Ponce and Carmona 2011), in experimental particulate density currents (Kubo and Nakajima 2002; Spinewine et al.
2009) and in sub- and proglacial fan deposits (Ghienne et al. 2010; Girard et al. 2012; Lang and Winsemann 2013). Such features are almost absent from other environments, suggesting that the particulate-density-current nature of the parental flows might be the source for stoss-aggrading bedforms (Rowley et al. 1985).

\section{Spatial evolution}

DBs are found to evolve in dimension (Douillet et al. 2013 and references therein), shape, and internal structure within deposits of the same eruption. Plate 24 of Richards (1959) shows DBs formed only after a break in slope, being absent above the break. The 1980 Mt. St. Helens (USA) eruption produced low-angle DBs (Fisher 1990) whose shape evolved downstream from hummocks to transverse shapes in the downstream direction (Hoblitt et al. 1981), and internal organization showing downstream crest migration on the stoss faces of ridges and upstream crest migration on ridge lee faces (Druitt 1992). Similarly, DBs from the 1982 eruption of El Chichón (México) have successive crests migrating upstream in proximal zones but migrating downstream in distal zones, interpreted as a result of downstream decrease in flow velocity (Sigurdsson et al. 1987). At Laacher See volcano (Germany), lensoidal layers aggrading on the upstream face of steep truncations interpreted as "chuteand-pool" structures were observed in more proximal zones than DB cross-stratifications with up- and downstream crest migration in distal zones (Schmincke et al. 1973). In contrast, at Roccamonfina (Italy) and Sugarloaf Mountain (USA) volcanoes, "chute-and-pool" structures as well as up- or downstream crest-migrating DB cross-stratifications occur within meters of each other (Cole 1991). In terms of their organization, DBs can also form composite bedforms built up by several successive DBs (e.g., Sigurdsson et al. 1987) or show a certain degree of repeatability in the downstream direction, suggesting periodic morphologies (Hoblitt et al. 1981).

\section{The 2006 eruption of Tungurahua}

Tungurahua is an active andesitic stratovolcano of the eastern Cordillera of the Northern Volcanic Zone in Ecuador (Hall et al. 1999, 2008; Le Pennec et al. 2008). The current period of activity began in 1999, reaching a paroxysm in July and August 2006, with generation of PDCs flowing down to populated areas, causing fatalities and severe damage to infrastructure and the agricultural sector. The 2006 PDCs were well-monitored and the deposits documented (Kelfoun et al. 2009; Samaniego et al. 2011; Eychenne et al. 2012; Douillet et al. 2013).

The July 14-16 PDCs flowed on the N-NW flanks. The more voluminous August 16-17 PDCs deposited on the N, W, and SW flanks, covering the July deposits. This paper focuses on the 
August deposits. The eruption lasted for less than $8 \mathrm{~h}$ and about five PDCs reached the study areas at approximate flow front velocities of $30 \mathrm{~m} / \mathrm{s}$ (inferred from seismic records; Kelfoun et al. 2009). The generation of the PDCs is believed to have resulted from the episodic destabilization of erupted products accumulated near the vent. Drainage channels directed the PDCs, confining the dense pyroclastic flows (Kelfoun et al. 2009). Cross-stratified, ash dominated deposits are found on the outer interfluves of valley curves and downstream of cliffs (Douillet et al. 2013). The cross-stratified deposits can be divided into a proximal $(P-X s t)$ and distal $(D-X s t)$ facies associations. On the upper flanks, $P$-Xst deposits are the signature of successive input from dense pyroclastic flows and dilute PDCs. On the lower flanks, the $D$-Xst deposits outcrop as isolated patches $100 \mathrm{~s}$ of meters broad and several meters thick that we refer to as "ash bodies" (Douillet et al. 2013). DBs produced by the eruption (C. Robin, personal communication) cover most of the surface of the Xst deposits, draped by a centimeter-thick fall layer confirming their pristine outer shapes (November 2010).

\section{Data}

\section{Measurements}

We measured the shape characteristics on the outer surface of more than 300 DBs from different depositional ash bodies. Since the outer surface corresponds either to a final lamina or truncation, our dataset should be comparable to others from cross-sections. The orientation of the crest and six shape parameters: length, thickness, width, stoss face length, stoss face slope angle, and lee face slope-angle were measured from eyewitness definition in the field (Fig. 1). Stoss and lee face slope angles are given here referred to the horizontal (i.e., not corrected for the mean underlying bed slope angle). Ripple index (RI; corresponding to the ratio of length over thickness) and ripple symmetry index (RSI; ratio of length of long face over length of short face) were calculated following Tanner (1967). High RI values characterize flat DBs, high RSI values asymmetrical DBs. The RSI ratio is always $>1$ : i.e., it does not distinguish whether the stoss or the lee face is longer. For Tungurahua, where DBs may exhibit a longer stoss or longer lee face, we allocated a sign to the RSI (termed signed RSI: "S-RSI"):

"S-RSI" = RSI if the stoss face is the longest;

"S-RSI" = -RSI if the lee face is the longest;

The six shape parameters are presented in four graphs (Fig. 3). The length vs. thickness data (Fig. 3a) follow a logarithmic trend that fits with other DB datasets from the literature and are in the middle range of sizes. Length versus width data (Fig. 3b) permit recognition of different shape patterns (see "Dune bedform types" section). In aeolian and subaqueous environments, a gentle stoss face ruled by erosion (theoretically) follows a steep lee face angle determined by the repose angle of the particles. However, at Tungurahua, the stoss and lee face slope angles vary significantly (Fig. 3c) and either side can be steeper. Laboratory measurements of the dynamic and static repose angles of dry bulk ash are $32^{\circ}$ and $41^{\circ}$, respectively, and $38^{\circ}$ and $52^{\circ}$ for the fraction $<250 \mu \mathrm{m}$. The majority of DBs from Tungurahua have negative SRSI values, indicating longer lee than stoss faces (Fig. 3d), though this can be an effect of the strong dip of the underlying bed (between $10^{\circ}$ and $25^{\circ}$ ). A scattered relation between RI and S-RSI is visible, indicating that flat bedforms tend to be more asymmetrical (Fig. 3d).

\section{Dune bedform types}

In the field, each DB was given a descriptive classification based on its overall morphology. Four common types were defined (Figs. 4, 5, 6, and 7): "elongate", "transverse", "lunate", and "two-dimensional". Cross-sections permit linkage of external shapes with internal stratification patterns. The main quantitative characteristics are listed in Table 1 and the six shape parameters grouped by color according to the DB type in Fig. 3.

\section{Elongate}

DBs from the P-Xst zone (see Douillet et al. 2013) are grouped under the term "elongate" as a reference to their usual shape. Usually, they are longer than wide, are the flattest (high RI) and have low-angle stoss faces. They produce only a slight bump on the surface of the deposits with diffuse crests that may be difficult to trace and have short stoss faces (high $\mathrm{S}$ RSI), possibly because they formed on the steepest slopes (Figs. 3c, d and 4.

Internally (Fig. 4b-e), elongate DBs shows aggrading patterns with a composite nature alternating between three lithofacies: (lensmBLA-facies, xsbAL-facies, and $m b A L-f a$ cies). The lensmBLA-facies consists of coarse-grained and massive layers made of an unsorted mixture of ash, lapilli, and blocks up to $10 \mathrm{~cm}$ in diameter. It sometimes shows gradational grain size changes. The layers vary between 3 and $20 \mathrm{~cm}$ in thickness and have a lensoidal shape. They thicken on the lower part of the stoss side and thin to the crest and on the lee, sometimes until they disappear, inducing an overall upstream migration of successive crests. The $x s b A L-$ facies consists of ash and lapilli bedsets that are crudely to diffusely laminated. Laminations usually show smooth crests and build up stoss-aggrading bedsets. The $m b A L$-facies is similar in grain size and bedset dimensions to the $x s b A$ facies, but massive. The contact between the three facies types can be sharp or gradational, and they may occur in 

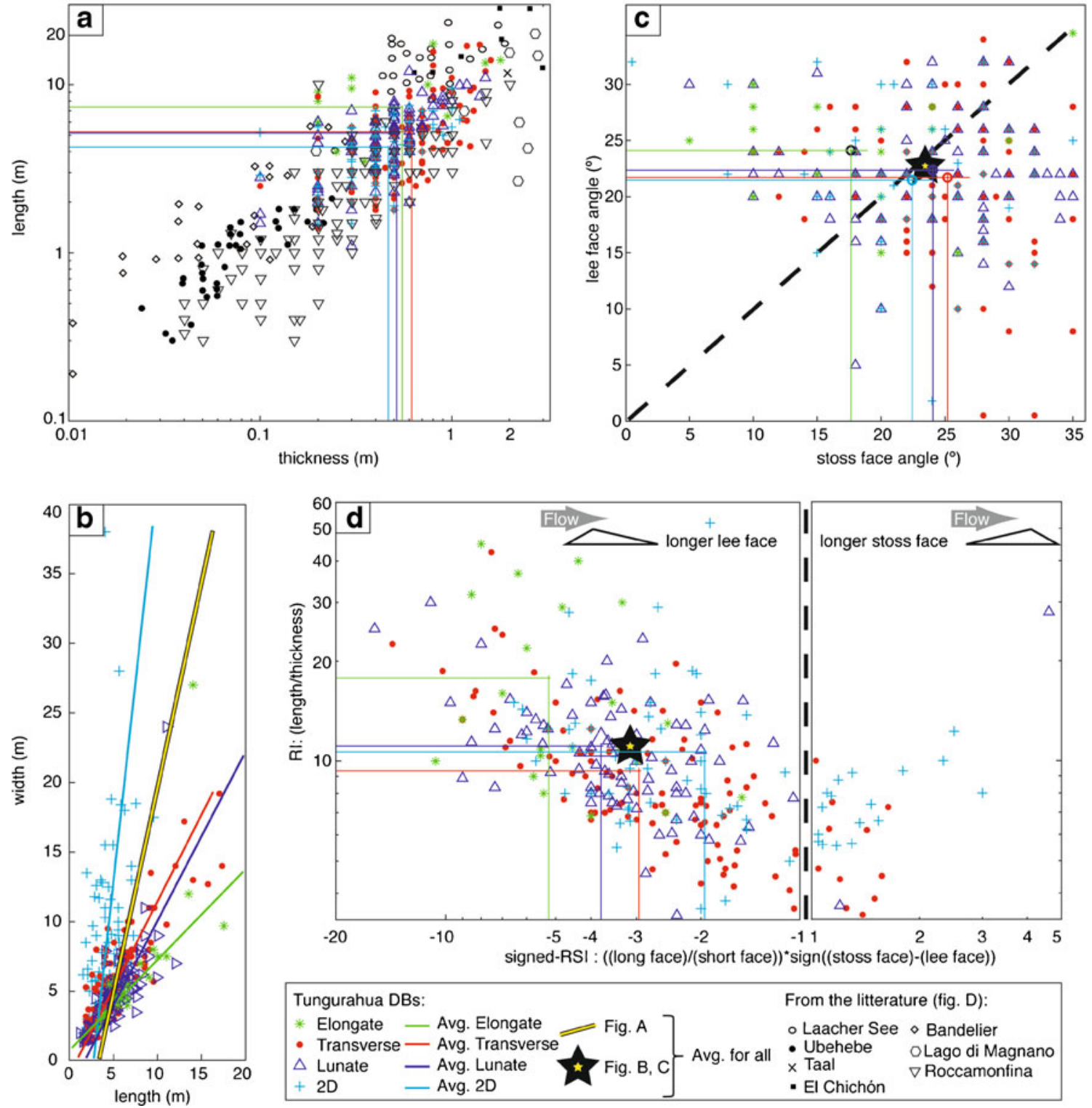

\begin{tabular}{|c|c|c|}
\hline Tungurahua DBs: & & From the litterature (fig. D): \\
\hline 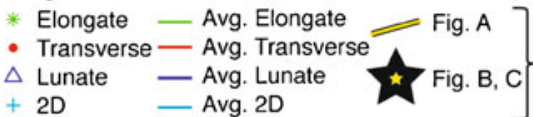 & - Avg. for all & $\begin{array}{ll}\text { - Laacher See } & \circ \text { Bandelier } \\
\text { - Ubehebe } & \text { OLago di Magnano } \\
\text { × Taal } & \nabla \text { Roccamonfina } \\
\text { - El Chichón } & \end{array}$ \\
\hline
\end{tabular}

Fig. 3 Dimensions of dune bedforms by types. a Length versus thickness, compared with outcrops from Ubehebe Crater (Crowe and Fisher 1973); Taal volcano (Waters and Fisher 1971); Laacher See (Schmincke et al. 1973); Bandelier Tuff and El Chichón (Sigurdsson et al. 1987); Bolsena caldera, Vico caldera, Baccano crater, and Martignano craterall four grouped under "Lago di Magnano"-(Mattson and Alvarez 1973); Roccamonfina (Gianneti and Luongo 1994); and Cora Maar

any order with the final strata forming a DB being made of any of the three facies. No correlation between different bedforms was possible. In one outcrop, a centimeter-thick, draping deposit of lapilli-sized ash aggregates without matrix was found intercalated between a lensmBLA layer and $x s b A L$ bedset.

Elongate DBs seem to nucleate without apparent underlying topography, but in gullies with deep exposure it is striking that the root of a bedform can be located several meters below the base of the surface expression. In that case, the structure
(Gençalioğlu-Kușcu et al. 2007). b Length versus width with linear regression. c Lee versus stoss face angles measured with respect to the horizontal line. The dotted line denotes equal lee and stoss angles. d Ripple index (length over width) as a function of signed ripple symmetry index (long face length over short face length, with negative sign indicating lee face longer than stoss)

alternates between several episodes of each facies, has truncations on stoss sides, but remains stable regarding its overall location.

\section{Transverse}

Transverse DBs have linear crests perpendicular to the (inferred) flow direction (Fig. 5a). Of all DBs, they show the broadest size variation and are characterized as relatively equivalent with respect to width versus length (Fig. 3, Table 1). 


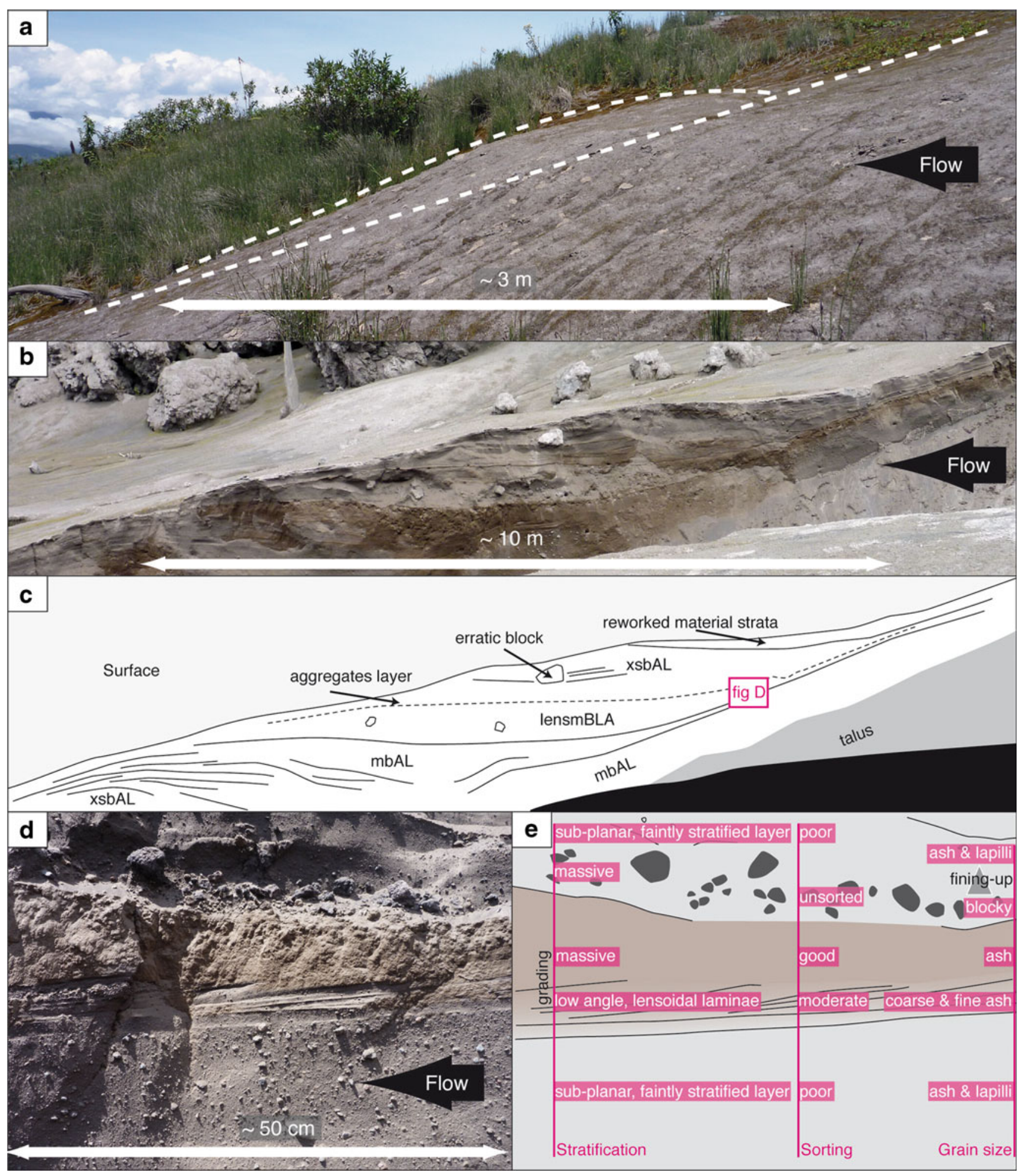

Fig. 4 Photographs of a the outer shape of an elongate dune bedform, $\mathbf{b}$ the internal structure of another elongate dune bedform, with $\mathbf{c}$ interpretation, and $\mathbf{d}$ zoom into the stratae with $\mathbf{e}$ interpretation. Note the (1)

aggrading lensoidal layers with upstream migration of the crest, (2) intercalation of massive layers ash or blocky material and cross stratified laminae

They have sharp crests and steep, straight faces (combined with low RI), and the stoss being often steeper than the lee.
Internal cross-stratification is formed by several crudely stratified bedsets of subcentimetric laminae of ash and of 


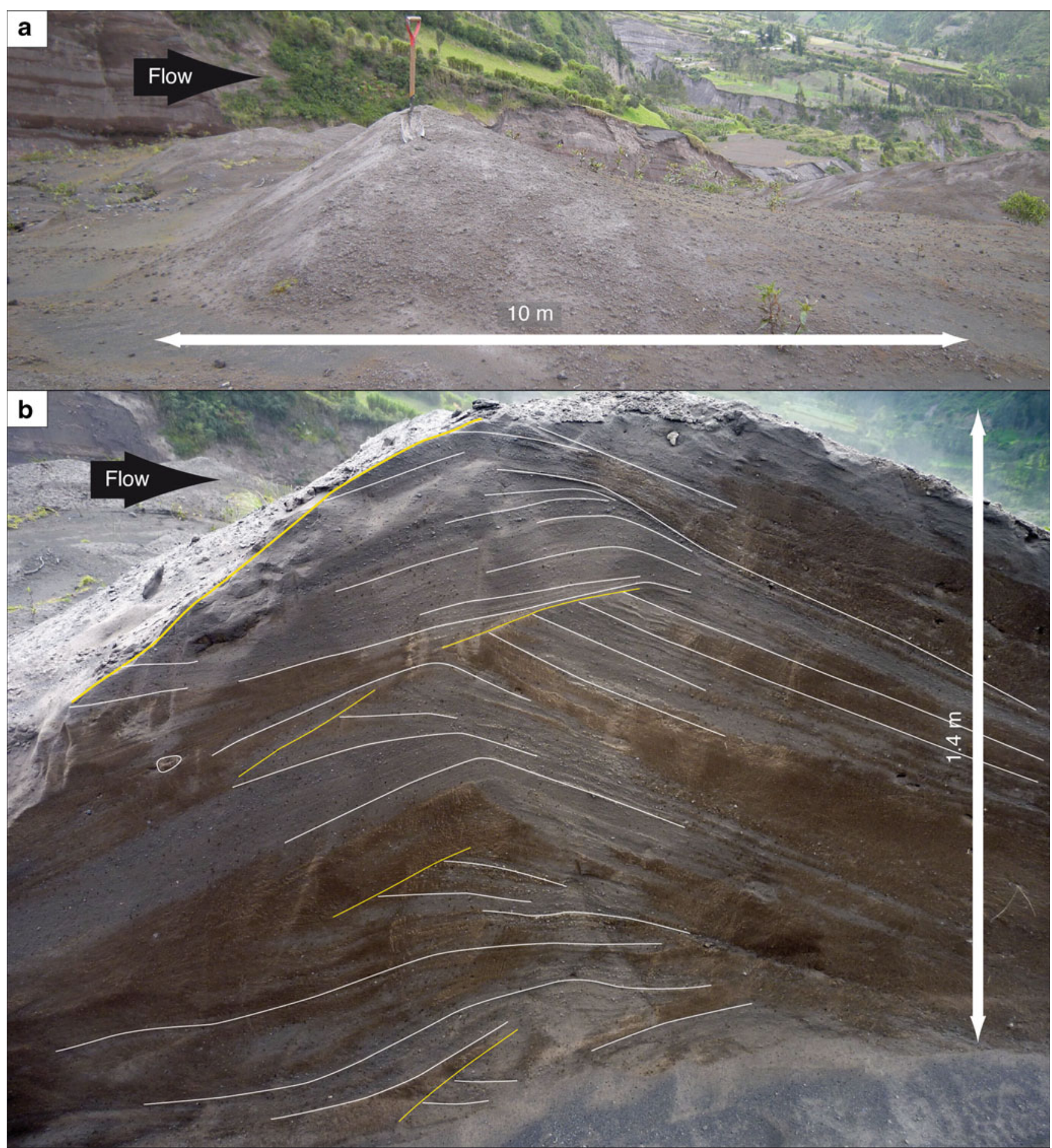

Fig. 5 Photographs of a the outer shape of a transverse dune bedform (shovel $1 \mathrm{~m}$ length) and $\mathbf{b}$ its internal structure. Note the (1) aggrading bedsets with upstream migration of the crest, (2) episodic truncations on

coarse ash (similar to the $x s b A L$-facies from elongates). Within a bedset, stoss aggradation dominates and induces an upstream crest migration. The aggrading bedsets are episodically truncated on stoss sides, but never on lee sides. These erosional episodes tend to sharpen the structures as the discordance planes are steeper than the aggrading bedsets. the stoss side with angle steeper than the laminae, (3) absence of truncations on the lee side, and (4) the basal laminations at the base of the structure

\section{Lunate}

Lunate DBs have a barchanoidal shape; that is, their crests are crescent-shaped and convex upstream (Fig. 6a). They have a thick body and thinning tails on the lateral ends (horns). We avoid the term "barchanoid" because barchan dunes form in 


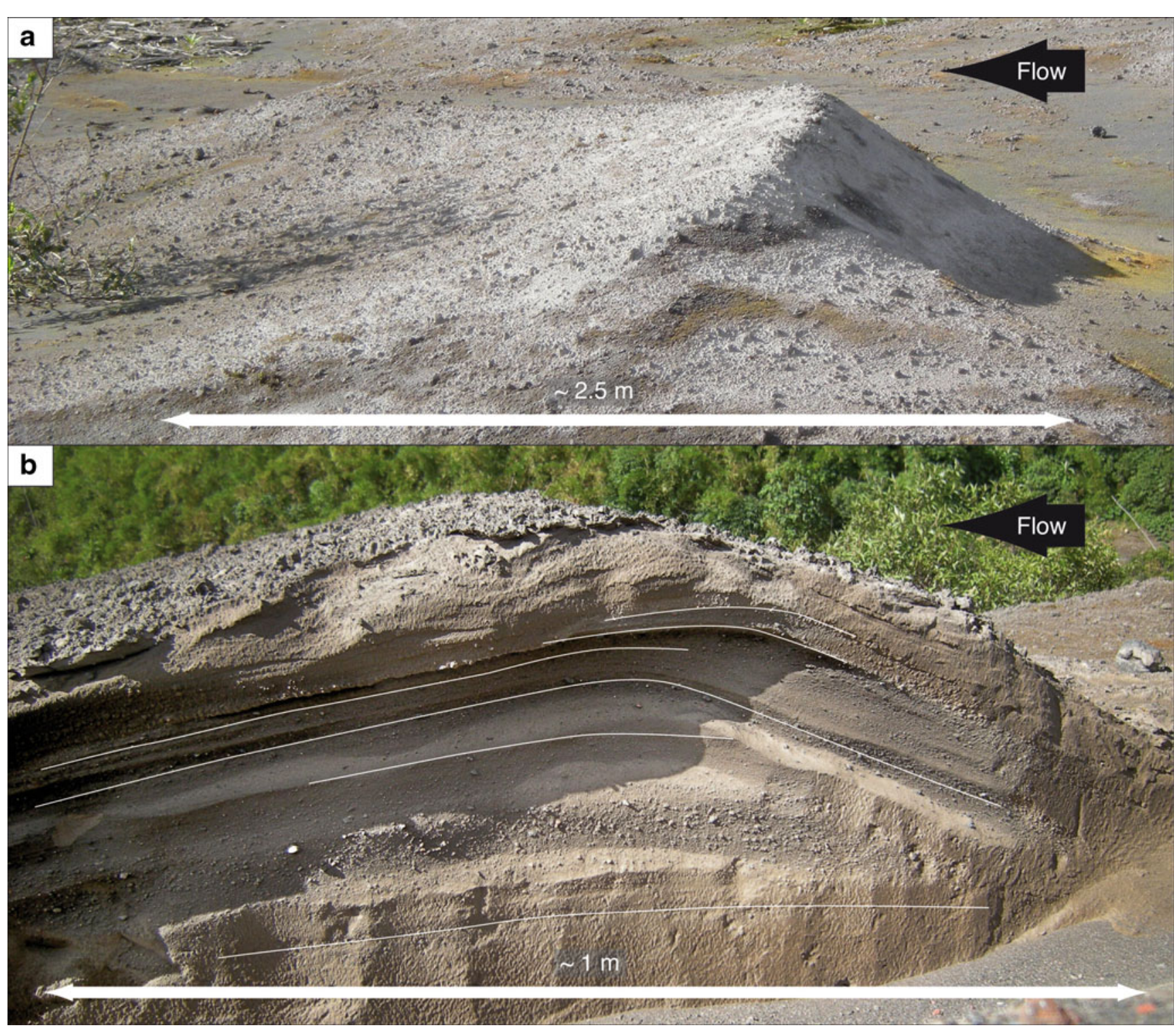

Fig. 6 Photograph of $\mathbf{a}$ the outer shape of a lunate dune bedform and $\mathbf{b}$ internal structure in another lunate dune bedform. Note: (1) aggrading structure, (2) upstream migration of the crest, and (3) variation in grain size between individual laminae

conditions of very low sediment supply. Lunate DBs have slightly smaller dimensions than elongate and transverse DBs. The face angles and average RI are comparable to those of transverse DBs (steep sided bedforms), but S-RSI and RSI are slightly greater than for transverse DBs (more asymmetrical; due to the long tails).

Internally, the observed cross-stratification is similar to the transverse type with stoss-aggrading bedsets, sharp crests and straight laminations on each side (Fig. 6b). The DBs seem to nucleate from flat streambeds and are thus not controlled by the underlying bed morphology.

\section{Two-dimensional}

The term "two-dimensional" (2D, Fig. 7) refers to 2D ripples that show similar characteristics: (1) linear crests perpendicular to the flow direction, (2) width greater than length, (3) organization in spatially recurring patterns in the flow direction (in train), and (4) almost symmetrical faces (Bridge and Demicco 2008, p. 231). Though both have linear crests, 2D DBs clearly distinguish from transverse on the length versus width graph (Fig. 3b). Face angles and average RI are in the middle range, but RI varies much more in this type (large 2D DBs are usually steep whereas smaller ones tend to be flat; Fig. 8a). 2D DBs have the smallest average thickness and S-RSI and RSI (most symmetrical), and the highest number of DBs with longer stoss face (positive S-RSI). They are organized in a spatially recurring pattern in the downstream direction (organization in train) and as such, can be given a wavelength (crest-to-crest distance; Fig. 7). The internal stratification patterns are not documented. 


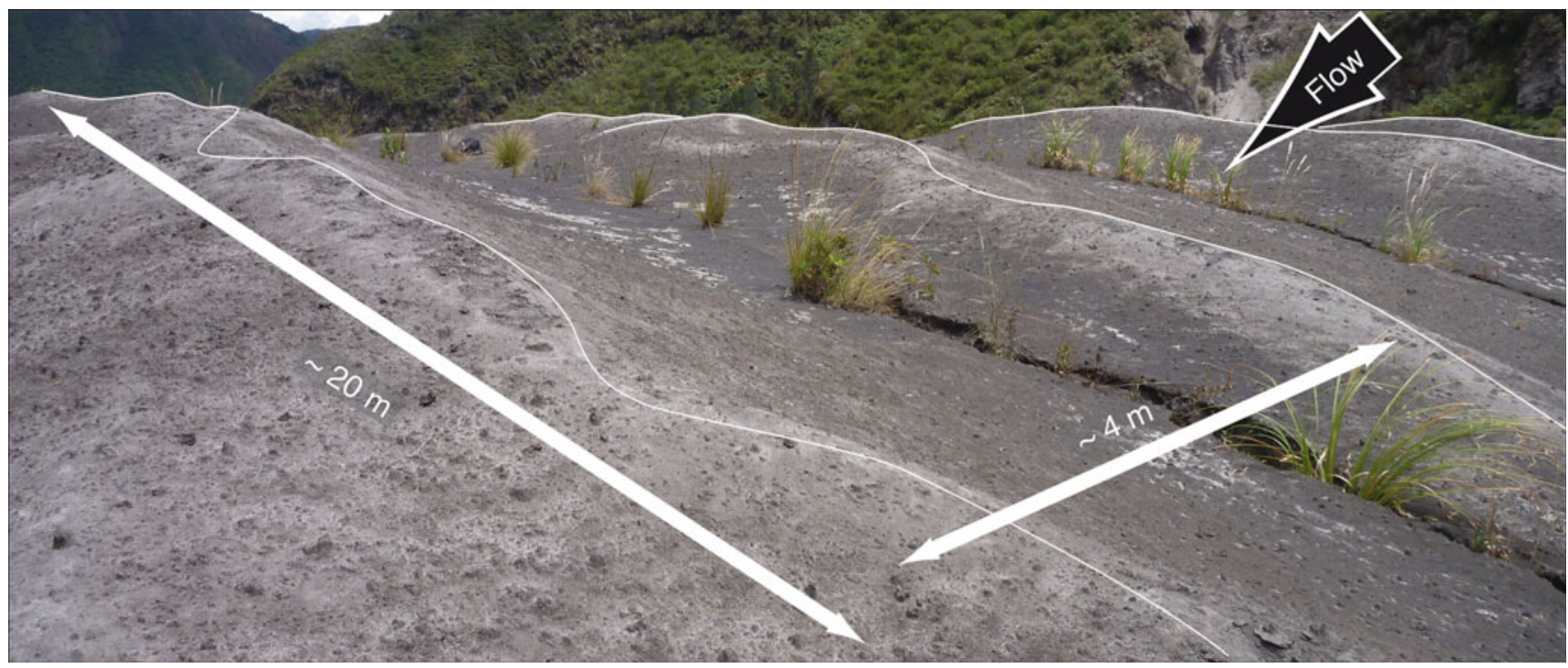

Fig. 7 Photograph of two dimensional dune bedforms. Note the significant width and short length as well as the repetition, in train in the downstream direction, of the same shape patterns

\section{Other types of $D B S$}

Other patterns have been observed but not investigated systematically (Fig. 7; group "other" in Electronic supplementary material (ESM) Table 2). Sporadic linguoid DBs are randomly distributed (crescentic crest but body pointing downstream, i.e., concave upstream; Fig. 8c). A single longitudinal DB (long crest parallel to flow direction; Cooke et al. 1993) has been found at the edge of the dense pyroclastic flow path behind a standing tree (1 $\mathrm{m}$ diameter; Fig. $8 \mathrm{~d})$. The apparent grain size of this DB is coarser and less sorted than the other types, including blocks of up to $10 \mathrm{~cm}$. The DB is $19.5 \mathrm{~m}$ long (parallel to flow), $4.8 \mathrm{~m}$ wide (perpendicular to flow), and $1.3 \mathrm{~m}$ thick. It is located close to transverse and lunate DBs. Numerous composite structures resulting from the superposition of several DBs have been observed (Fig. 8e), with imbrications of both small and large DBs, superimposed on the lee face of one another. Other types of composite shapes have diverging and doubled crests, either resulting from the splitting of an initial DB or rather from the merging of two DBs with different orientation. "V shaped" DBs occur in zones dominated by lunate and 2D DBs. Steeply incised, very local truncations filled with massive ash are also observed (Fig. 8b). The virtual absence of ripple-sized cross-lamination is noteworthy.

\section{Granulometry}

Twenty-six samples were collected on the stoss and lee sides of 13 DBs from different deposition zones (see Douillet et al. 2013). Stoss samples are slightly better sorted and coarser grained (average $\sigma, 1.42 ; \mathrm{Md}, 2.87$ ) than lee ones (average $\sigma, 1.58$; Md, 2.82; Fig. 9). This generally supports the inference that cross-stratification is related to tractional processes: stoss faces being slightly more exposed to traction, they have a tendency to be fines depleted (coarsening the median grain size and improving the sorting; Nakajima and Satoh 2001).

\section{Spatial distribution}

The four DB types are observed to outcrop with a spatial evolution, analyzed for the main deposition zones (Chontal (Fig. 10) and Achupashal (Fig. 11)). A general description and interpretation of the dilute PDC deposits can be found in Douillet et al. (2013).

\section{Proximal zone}

The proximal cross-stratified deposits outcrop as a wide sheet on the overbanks of smoothly incised valleys on the steep (up to $25^{\circ}$ ) upper slope of the volcano. There, dilute PDCs are interpreted to derive from the dense flows by air entrainment and the depositional area was affected by both dilute and dense flows. Although their shape can vary, DBs of this zone have all been grouped as "elongates", a choice justified by their clear deviation from the other types in quantitative measurements and the fact that their composite stratification patterns have not been observed in other deposition zones. They occur in isolation at large distances from each other and no downstream size decrease is apparent.

\section{Distal zones}

In distal zones, PDCs were confined mainly to deep channels of the drainage network. While dense pyroclastic flow 
deposits are confined to thalwegs, cross-stratified, isolated, wedge-shaped ash bodies a few hundred meters across outcrop on the outer overbanks of valley curves. Deposition is related to dilute PDCs that overflowed the valleys, and possibly experienced a hydraulic jump of the entire current or at least strong deceleration during deposition. DBs with the largest dimensions are observed at the upstream onset of the ash bodies. A decrease in length, thickness, and width of the DBs (grayscale in Figs. 10 and 11) follows the currents' direction, reconstructed from their orientation, together with an evolution from transverse, to lunate, to 2D shapes.

(a) Chontal

The Chontal ash body is bordered by two curving valleys and was deposited by dilute PDCs overflowing from both of them (Fig. 10). A clear evolution of the DB type is visible: At the upstream limit (SW), only large transverse DBs outcrop, organized in train with the sharp onset of the ash body (the only transverse DBs observed in train). Close to the eastern valley, DBs are smaller and lunate shapes occur together with transverse ones. 2D DBs are exclusively found on the edge of the DB field, where spreading of the flows was possible. At the downstream end of the ash body, DBs diminish in size until no more DBs outcrop (November 2010).

(b) Cusua

The Cusua ash body is located on the outer overbank of a valley curve (Fig. 11b). The northern border is forced by a topographic barrier that blocked spreading. Shape evolution of the DBs is less pronounced than for Chontal, but still noticeable. Transverse DBs are distributed across the entire ash body but dominate at the upstream limit. Lunate DBs occur in the middle and lower part of the ash body but are absent near the upstream limit. 2D DBs are mainly located on the southern and western edges of the ash body, i.e., away from the source and from the topographic barrier, where flows were free to spread. Only one 2D DB was found in the northern part.

(c) Chacauco

At the base of the volcanic edifice, dilute PDCs "jumped" the Chambo River and reached the village of Chacauco on the opposite bank. There, topography sloped counter to the flow direction, forcing slowing, and spreading of the currents. Only 2D DBs (except 2 transverse) developed and formed concentric trains away from the source valley (Fig. 11a).

\section{Interpretation}

Flow conditions during deposition of PDCs affect the sedimentary record, providing the opportunity to infer the 


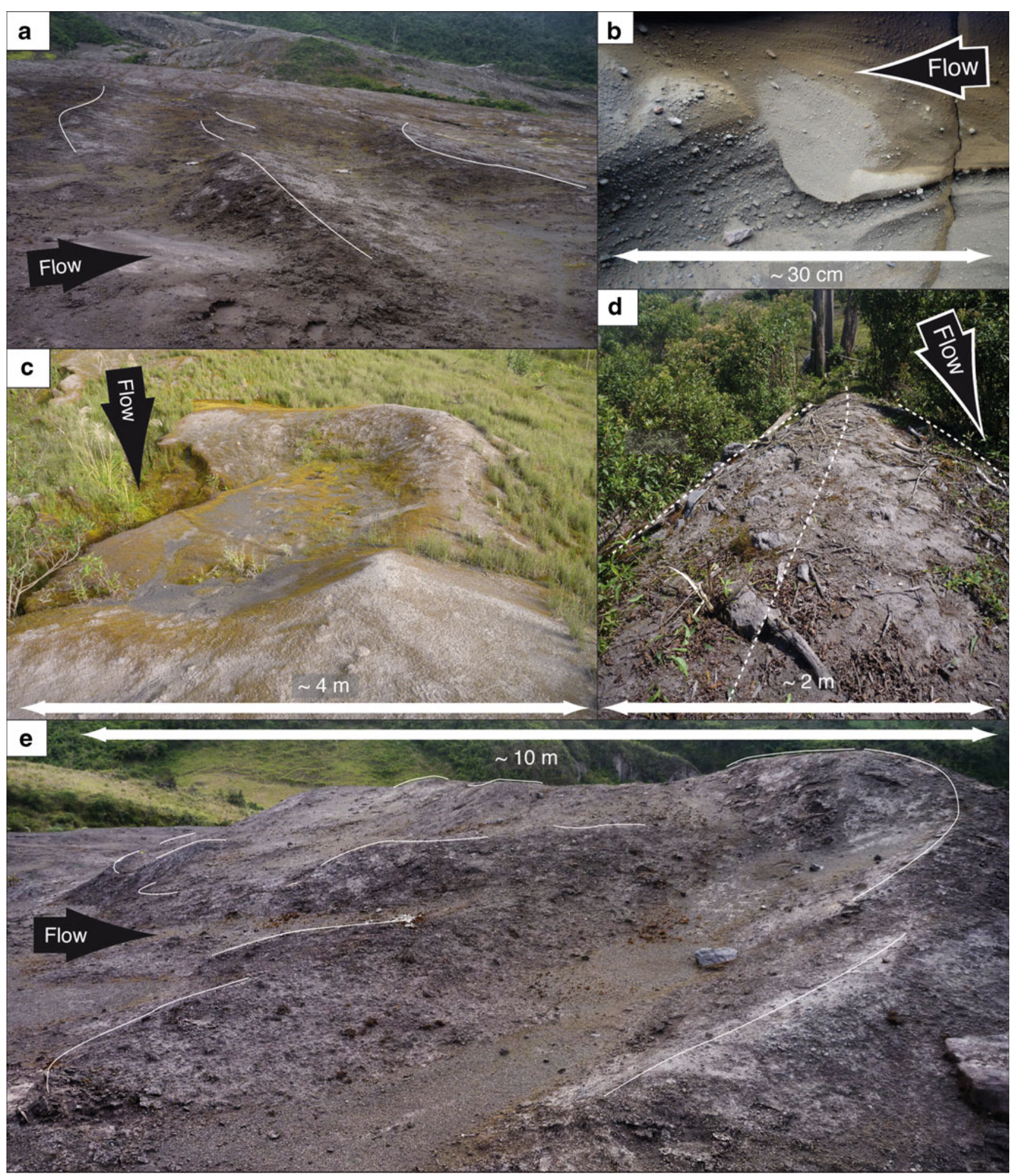

Fig. 8 a Small-scale 2D DB train, b cut-and-fill structure of faintly stratified ash and lapilli, $\mathbf{c}$ crescentic DB or alternatively the crater from the impact of a large block, $\mathbf{d}$ longitudinal DB behind a tree (the base of the tree is not visible), e composite DB cluster formed with several imbricated crests

dynamics of the parent currents. However, caution must be exercised when interpreting the sedimentary record, since different conditions may produce similar bedforms. The accent should always be put on a careful description independent of any interpretation. In the following section, we distinguish between dunes and antidunes and discuss the antidune interpretation for the DBs at Tungurahua. We then individually interpret each DB type and suggest a new 


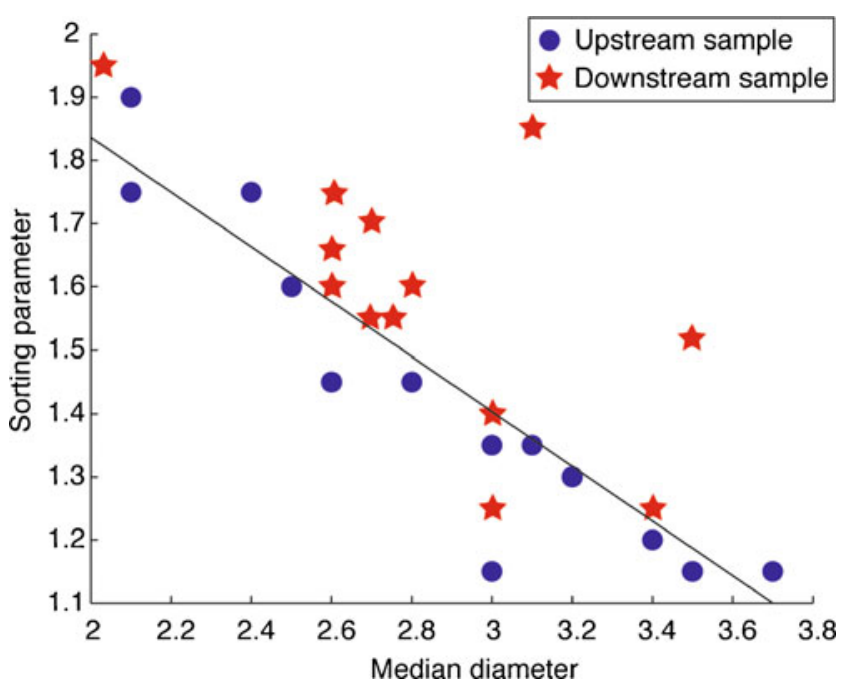

Fig. 9 Sorting parameter versus median diameter of material sampled on pairs of stoss and lee sides from 13 dune bedforms. Stoss samples are better sorted and coarser-grained, arbitrary line separates most stoss vs. lee points

interpretative term: "regressive climbing dune" for the stoss aggrading, steep sided, and regressive bedsets found in distal areas.

Fluid dynamics of antidunes, dunes, and climbing dunes

In the past decades, many DBs in the deposits of PDCs have been described and/or interpreted as antidunes or climbing dunes. Both terms however refer to strict fluid dynamics

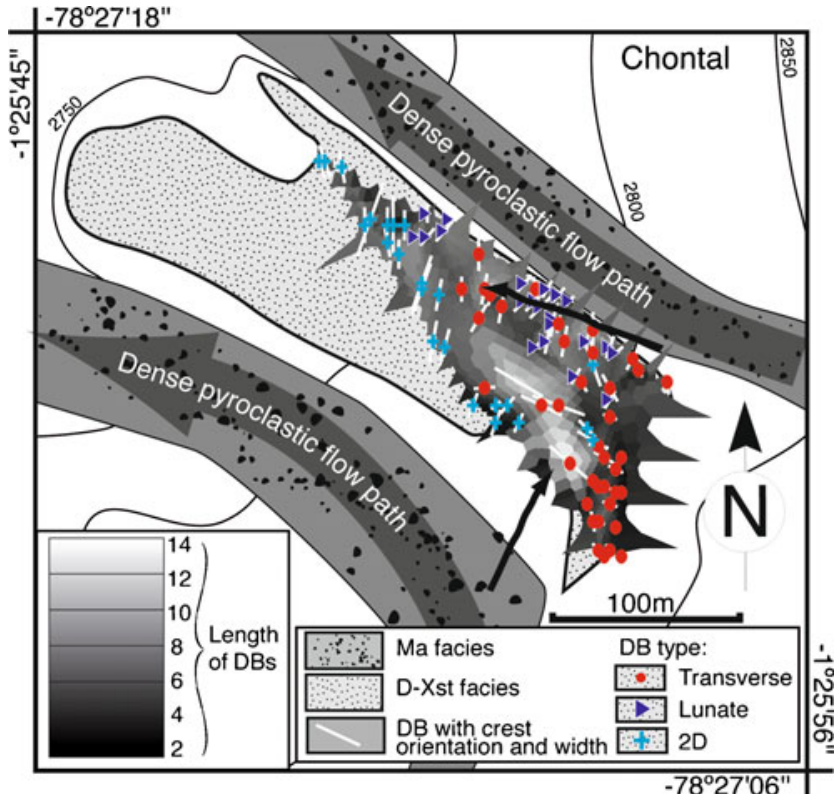

Fig. 10 Map of Chontal ash body. The thickness of dune bedforms is represented in grayscale and the orientation of the crests as well as the width of individual dune bedforms are given by white lines (see Douillet et al. 2013) considerations, and are thus interpretative terms of the growth of a sedimentary structure. Dunes (including climbing dunes!) are exclusively the product of subcritical flows, whereas antidunes are related to trans- and supercritical flows and stationary gravity waves (Bridge and Demicco 2008, p. 181).

When sedimentation occurs at the base of a stationary gravity wave, an antidune can be produced with its shape and wavelength related to those of the gravity wave at the density interface (Hand 1969; Kubo and Nakajima 2002). The wavelength may be used to derive information on flow velocity and thickness as well as the density interface (Prave 1990). If the gravity wave is not perfectly stationary, the coupled antidune/gravity wave moves together and the antidune can migrate upstream or downstream, i.e., up- or downstream migration is not indicative of the flow regime (Kubo and Nakajima 2002; Spinewine et al. 2009).

Dunes sensus stricto consist of DBs produced under subcritical conditions (Froude number, $<1$; Bridge and Demicco 2008, p. 163). An open flow (i.e., with a free upper surface) in subcritical regime decreases in thickness and accelerates over an increase in streambed elevation (Branney and Kokelaar 2002, p. 19; Guyon et al. 2001, p. 289). As such, its capacity and competence will increase, possibly leading to erosion on the stoss face of a DB. Beyond the "crest", the decrease in streambed elevation leads to flow deceleration and thickness increase, possibly inducing deposition on the lee face.

Constructional cross-stratification (such as climbing crosslaminations) is produced when the angle of climb equals or exceeds the angle of the stoss side, indicating more aggradation than erosion (Bridge and Demicco 2008, p. 176). Whereas climbing ripples are common in the sedimentary record, climbing dunes are rarer. Examples are found in turbidites, glaciogenic subaqueous fans or glacial outburst flood deposits, and dilute PDC deposits (Ghienne et al. 2010 and references therein). All of these are related to particle-driven density currents. If the deposition rate supersedes erosion on the stoss side, the latter is not completely eroded during migration, stoss side laminae are preserved, aggrading structures are produced and the full geometry of the original structure is observed. The angle of climb depends on the ratio of deposition to bedload transport (Allen 1970): the more deposition (from suspended load), the steeper the angle of climb. In the extreme case, laminae would emplace as fallout and drape the bedform to produce symmetrical structure on the pre-existing bedform with no bedload (lateral) transport (Ashley et al. 1982). It is thus not possible to explain upstream crest migrating structures with this scheme because deposition must be more important on the lee than on the stoss face for a dune (subcritical regime).

In the case of a thick homogenous flow (e.g., for a waterair interface, when the flow depth is greater than twice the wavelength of the bedform; Bridge and Demicco 2008, p. 181), antidunes cannot form because there is no interface close 


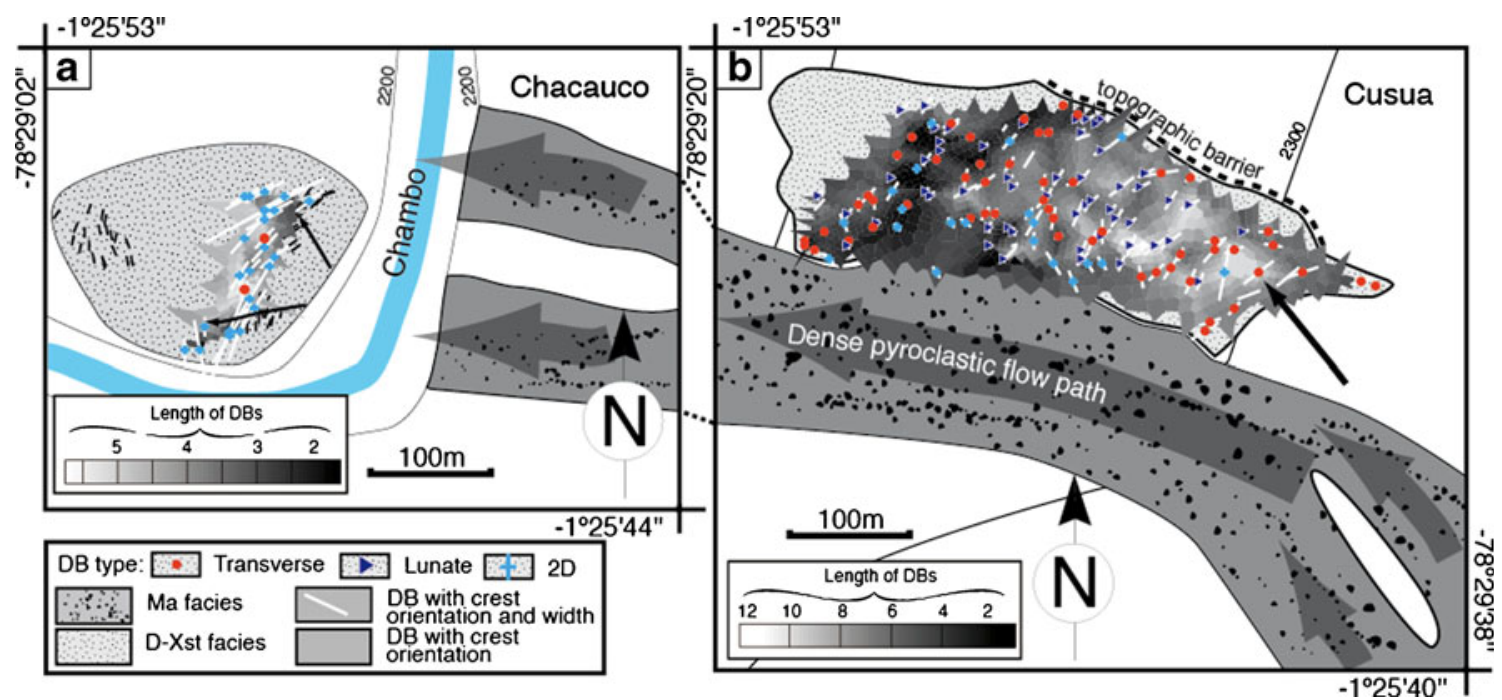

Fig. 11 Maps of ash bodies in Achupashal valley. a Lowermost zone of Chacauco ash body. b Cusua ash body. Dune bedform types follow the same coding as for Fig. 10

to the bed that can trap internal gravity waves and shape the bed. Yet, DBs can be active without a free boundary. Indeed, a positive streambed morphology will reduce the section of the flow and cause acceleration over the stoss face whereas deceleration is experienced on the lee with possible formation of a separation vortex for a short distance downstream. Thus, a downstream migrating DB can be produced. In such a case, the DB does not hold information on the flow thickness. Distinction between DBs related to a flow interface (Bridge and Demicco 2008, p. 169; Lorenz et al. 2010) and DBs related to self-production of a separation vortex on the lee (as is often the case for aeolian dunes) is an important issue in understanding flow stratification within dilute PDCs.

We believe that the development of stationary gravity waves of meter-scale wavelength is unlikely in dilute PDCs. Indeed, stationary waves require relative steadiness and static stability and dilute PDCs are thought to be highly turbulent, pulsatile and unsteady flows, at least near the base (Kieffer and Sturtevant 1988; Andrews and Manga 2012). The existence of a sharp internal flow interface within dilute PDCs is questionable and it seems more likely that they show a continuous density gradient, not prone to trap internal gravity waves. Moreover, stossaggrading bedforms, often seen as indicators of stationary gravity waves, are not necessarily related to antidunes, since deposition of particles is not simply driven by the dynamics of the fluid phase (Nakajima and Satoh 2001). Indeed, when a subcritical current flows over positive topography, deposition may be caused even if the flow itself accelerates, because the increase in flow velocity (and turbulent entrainment) might be not insufficient to carry the particles over the obstacle (Kubo and Nakajima 2002). Dilute PDCs may be especially prone to such a scenario, because particles are gas-supported, and the entrainment of particles by gas with low viscosity is not as strong as by water.

Using geometrical relationships of the DBs, we demonstrate the inadequacy of interpreting steep DBs as antidunes: we observed DBs with a length of $10 \mathrm{~m}$, a stoss angle of $35^{\circ}$ and a thickness of $1.6 \mathrm{~m}$. The wavelength of a (stationary) gravity wave trapped at a density interface needs to be at least 12 times greater than the thickness of the underflow and this ratio increases with the density contrast (Hand et al. 1972; Prave 1990). Thus, a $10 \mathrm{~m}$ long $\mathrm{DB}$, associated with a $10 \mathrm{~m}$ wavelength stationary gravity wave, would imply an underflow thinner than $0.8 \mathrm{~m}$. It is rather unlikely that a $0.8 \mathrm{~m}$ thick flow would stay in supercritical conditions while climbing a $1.6 \mathrm{~m}$ high slope at $35^{\circ}$ and produce a gravity wave with amplitude (equal to the thickness of the DB) twice that of the flow thickness. Thus, it seems unlikely that steep DBs are antidunes. Furthermore, truncations are observed only on laminae of the stoss side and never on the lee side. This shows that these truncations are not related to antidune formation. Indeed, if these structures were produced by a gravity wave moving slightly upstream (to account for the upstream migration of the crests), one should observe truncations on the lee sides, or the wavelength of the gravity wave should increase during building of the cross-stratification. Thus, neither the steep transverse, nor the lunate nor 2D DBs can be interpreted as antidunes.

Dune bedform types

\section{Elongates}

In elongate DBs, the lensmBLA-facies layers are interpreted to be related to dense flows, since dilute PDCs would be unlikely 
to be able to transport the largest blocks. In contrast, the $x s b A L$-facies bedsets derive from fully dilute PDCs with tractional flow boundaries, and the $m b A L$-facies from dilute PDCs where the rate of supply exceeded the rate of deposition, favoring the development of a concentrated zone that inhibited stratification (Branney and Kokelaar 1997; Sulpizio et al. 2010), possibly with a traction carpet (Sohn 1997; Fig. 12a-d). The borders between the facies within a DB can be sharp or gradational, showing that the flow types could evolve into each other or occur individually. These interpretations are supported by the exclusive location of elongate patterns in proximal zones, where PDCs were barely confined by topography and a gradation between dense pyroclastic flows and dilute PDCs is to be expected, and by their absence in distal zones, where only dilute PDC occurred. The coarseness and flatness of the lensmBLA-facies lensoidal layers suggest a high capacity (ability to transport) and competence (erosiveness) of the flows, otherwise, the layers would build more steeply. The intercalated $x s b A L$-facies bedsets are steeper and similar to distal patterns, though they tend to grade from (or into) $m b A L$-facies .

The flat and upstream migrating patterns of lensmBLA-facies found in elongate DBs are strikingly similar to: (1) structures produced in experimental subaqueous density currents
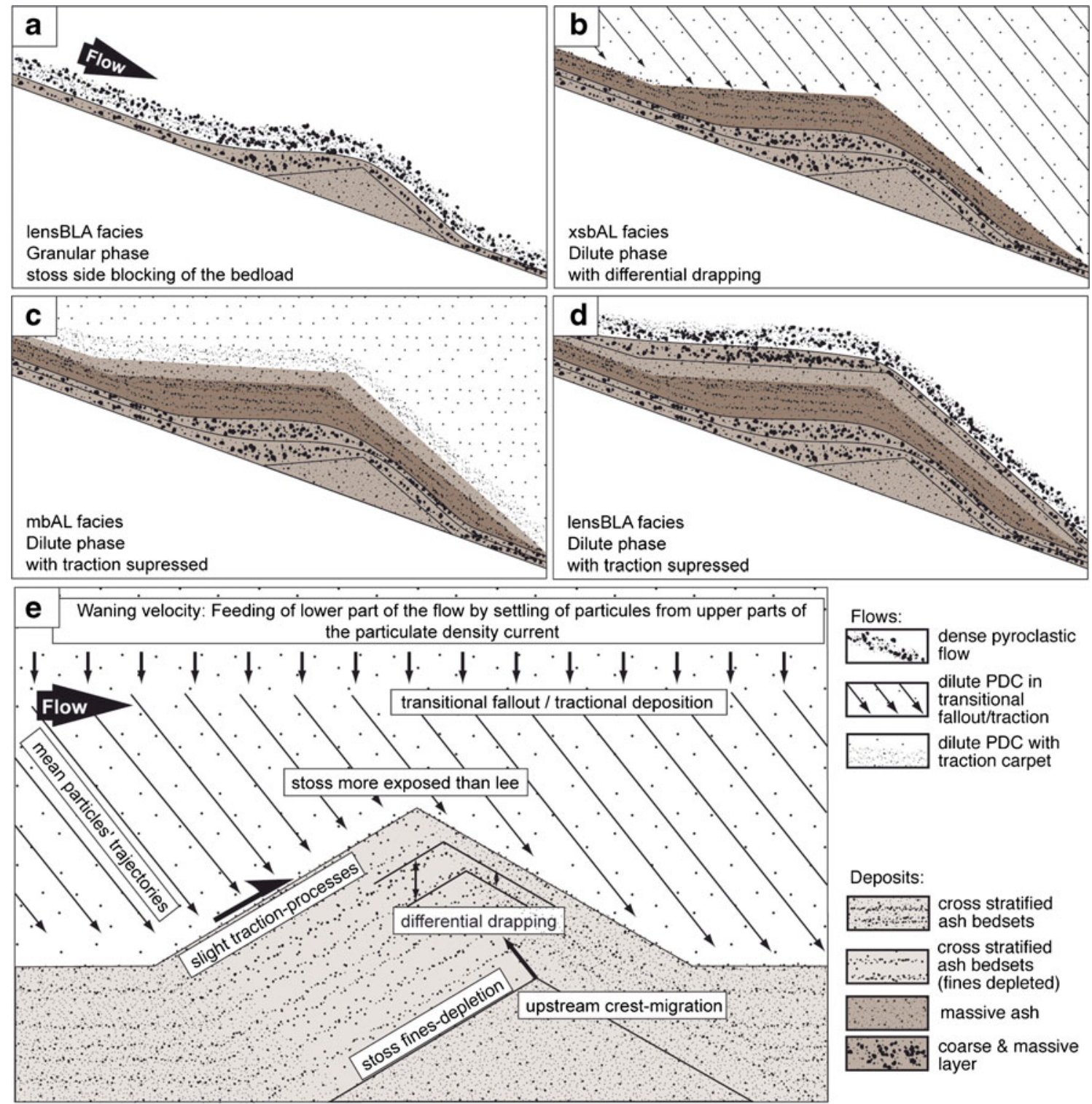

Fig. 12 Interpretative sketch of $\mathbf{a}, \mathbf{b}, \mathbf{c}$, and $\mathbf{d}$, the formation of elongate DBs by successive flows, and $\mathbf{e}$ : regressive climbing dune. Currents are represented with grains only, deposits with grains, and background colors. a Granular phases deposit lensmBLA layers; b dilute phase deposits $x s b A L$ bedset; $\mathbf{c}$ dilute phase with traction suppressed by high basal concentration deposits $m b A L$ bedset; $\mathbf{d}$ granular phase deposits lensmBLA layer. e Regressive climbing dunes are formed by the differential exposition between stoss and lee faces, in turns driven by the mean particle trajectories that have a fall and a lateral component, together with little traction after initial landing 
interpreted as cyclic steps (Fig. 6a of Spinewine et al. 2009), (2) types I and II DBs from Schmincke et al. (1973), interpreted as "chute-and-pool" structures, and (3) antidunes produced in water tanks (Hand 1974; Fig. 5 in Cheel (1990)). Moreover, they only occur in steep proximal zones. These factors may contribute to their diagnosis as antidunes or "chute-and-pool" structures. However, contrary to the Schmincke et al. (1973) "chuteand-pool" structures, the elongate DBs do not aggrade against the stoss face of a truncation surface, but nucleate without any apparent initial streambed topography. Yet "chute-and-pool" structures (an end-member of cyclic steps) have a length related to their grain size (Alexander 2008), and as such, different layers should have similar granulometry, or show truncations, which is not observed at Tungurahua.

Concerning interpretation as antidunes, only the lensmBLAfacies layers have the lensoidal, stoss-aggrading shape that would favor this interpretation. However, these are related to dense pyroclastic flows. The draping layer of accreted-ash lapillis found intercalated between coarser layers is interpreted as a fallout deposit, showing that such DBs continued their growth over different pulses or flows, as suggested by Walker (1984), Cole (1991), and Sulpizio et al. (2007). It seems unlikely that two stationary gravity waves of the same wavelength would emplace at the same place (they are free boundary related) for two different flows and contribute to the growth of a single antidune (unless interaction of the second flow with the DB produced a "forced" stationary wave). Rather than assign these as antidunes, we suggest that the bedslope decrease induced on the stoss side of the bedform would lead to blocking of parts of the bedload causing stossaggradation without the flow necessarily being in a transor supercritical condition, as suggested for turbidites (basal lenses of Ponce and Carmona 2011). The xsbALfacies bedsets have similar characteristics to the distal DBs, and the same argument holds (see below).

\section{Transverse}

Transverse DBs are formed by finely laminated bedsets of ash, indicating emplacement by turbulent and fully dilute currents with a tractional basal flow boundary. Since the number of bedsets found within a single DB exceeds the likely number of PDCs having flowed in the zone, each bedset (and not each laminae, as suggested by Cole (1991) or Sulpizio et al. (2007)) most probably relates to individual pulses within a single PDC rather than to individual PDCs. Within each pulse, turbulence eddies produce the lamination (Bridge and Demicco 2008, Chap. 3).

Bedset truncation steepens the structures. These truncations cannot result from simple collisions of saltons during saltation, which should produce a flat erosive plane, as in the aeolian context. Rather, we suggest that these truncations are linked with high-energy bursts linked to single eddies.
The transverse DBs (with steep stoss- and lee-sides angles close to the repose angle) suggest low capacity and/or slow flows, otherwise, such steep unconsolidated structures would be eroded. Moreover, the structures are mainly aggrading, with construction on both sides. The currents must thus have had an entirely depositional dynamic with much higher particle concentrations than the saturated transport capacity.

\section{Lunate}

The similarity in internal structure of lunate and transverse DBs as well as their spatial proximity leads to the same interpretation of the flows producing them: turbulent, fully dilute, low capacity flows with a tractional basal flow boundary, entirely depositional dynamics with higher particle concentration than the saturated transport capacity, and each bedset corresponding to a pulse.

The shape is however strikingly different and can result from a process influenced by the thickness of the obstacle: possibly, the thicker the obstacle, the more it blocks the current and promotes stoss aggradation. As the thin parts block fewer particles, they are less subject to stoss side aggradation, and the crests of the tails migrate upstream at slower rates. This does not explain why some DBs become lunate and others transverse. Moreover, lunate shapes are located at Chontal where currents emanated from two valleys with different directions, and in lower zones of Cusua, but are absent in the uppermost zones where currents were more likely unidirectional. Thus they possibly result from currents with different directions. Information on their $3 \mathrm{D}$ internal structure is required to ensure that the tails are not the remains of late-stage erosion of a larger $\mathrm{DB}$, or contain evidence of two current directions.

\section{$2 D$}

2D DBs may form when lateral transport is more important than downstream transport. Numerical simulations from a random bed configuration with the constraint that lateral transport exceeds downstream transport result in formation of 2D DBs (Rubin 2010). This is particularly interesting at Tungurahua as 2D DBs are found on the unconfined edges of ash bodies, where flows are likely to spread, thus having a strong lateral component. Similarly, the Chacauco ash body dips against flow direction and forces lateral spreading of the flows.

Even if they have periodic morphologies and are the most symmetrical, the emplacement of 2D DBs on the lower and outer edges of deposition zones (and downstream from transverse and lunate DBs) is not in agreement with interpretation as antidunes. 


\section{Composite DBs}

The "V" shaped DBs sporadically observed may result from the convergence of two small 2D DBs with different orientations during a single event, or successive currents with different flow directions. They could also represent extreme cases of lunate DBs; systematic cross sections are needed to constrain their genesis.

Contrary to previous suggestions for other similar features (Nemoto and Yoshida 2009), the composite DBs at Tungurahua are not interpreted here as antidunes, since it is unlikely that several stationary gravity waves would occur at the same place to produce accreting structures. In the aeolian context, composite ripples are interpreted as a transitory state in the organization of fully developed trains (Anderson 1990). Accordingly, composite DBs at Tungurahua are interpreted as DBs that did not reach equilibrium by the end of the events.

The longitudinal dune observed behind a tree at the edge of the pathway of dense pyroclastic flows is formed by massive, unsorted, and coarse deposits. It is interpreted as deposited from a dense flow in the pressure shadow of the tree rather than by tractional currents.

\section{Regressive climbing dunes}

Here, we introduce and justify a new interpretative term "regressive climbing dunes". The aggrading nature of both transverse and lunate DBs cannot be interpreted as climbing dunes, since climbing dunes never show upstream crest migration (see "Interpretations" section). Similar structures have been observed in turbidites (Mulder et al. 2009; Ponce and Carmona 2011) even if a controversy exists regarding their interpretation (Higgs 2011). One interesting interpretation invokes differential draping from suspended load to account for upstream migrating structures (Nakajima and Satoh 2001; Kubo and Nakajima 2002; Ponce and Carmona 2011). The similarity between PDCs and turbidity currents is that they are both particulate density currents and as such, the agent of excess density (the particles) is not a conserved quantity (particles can deposit or be entrained). Since a density current is accelerated by its greater density than the ambient medium, it should decelerate when deposition begins, in turn further increasing deposition and so on (e.g., the dilute PDC pulses depositing laminae "en masse" of Sulpizio et al. (2007)). Ponce and Carmona (2011) use the term differential draping for stoss-aggrading bedforms deposited from turbidity currents. We suggest that this "differential draping" also occurs for DBs in dilute PDCs. The increased sedimentation on the stoss face would result from the suspended charge that deposit. Since deposition decreases flow energy for a particulate density current, freshly landed particles cannot be further transported as bedload. The trajectory of particles depositing from suspended load being the combination of a vertical fall component and a lateral transport component, the stoss side of the bedform is more exposed than the lee side (Fig. 12e). In the case of direct deposition from suspension without a splashing effect and no further transport (e.g., saltation), the stoss face would experience more aggradation than the lee. This implies rapidly decelerating and slow currents to reduce bedload transport and lead to major direct sedimentation of the suspended load (as suggested by Ponce and Carmona (2011)). Such a process may be triggered if basal parts of the flow benefit from high rates of supply by settling of particles from the upper parts of the flow, favoring saturated transport at the boundary (but still below granular boundary conditions).

Fine-grained and finely laminated, aggrading and upstream crest migrating structures are thus transitional between direct fallout and tractional flow boundary processes, with the traction base not inhibited by high supply rates. This is in accordance with the interpretation that hydraulic jumps of the entire PDCs led to emplacement of the cross-stratified ash wedges (see Douillet et al. 2013, also suggested in glacial outburst deposits by Ghienne et al. (2010)). We introduce the term "regressive climbing dunes" for aggrading structures that exhibit upstream migration of the crests due to high supply and deposition from suspension (differential drapping) but little bedload reworking, in subcritical conditions (i.e., unrelated to antidunes). "Regressive climbing dunes" are in agreement with different conceptual models of waning flows (Cole 1991; Walker 1984; Sulpizio et al. 2007; Vasquez and Ort 2006; Ponce and Carmona 2011). This term includes a genetic interpretation and is interpretative, not descriptive. It also applies for other types of particulate density currents such as turbidity currents or hyperpycnal flows.

\section{Conclusion}

The genesis of DBs deposited from dilute PDCs deserves further investigation. In particular, a better understanding of their link to a flow interface (at an upper flow boundary, like for fluvial dunes) or basal flow boundary (like for aeolian ripples) is required. It is therefore fundamental to differentiate between descriptive patterns (e.g., foreset/backset lamination, aggrading structure, evolution of laminae thickness, truncations, steepness to bed, or horizontal) and interpretations (e.g., dunes, antidunes, climbing dunes, and "chute-and-pool" structures). Interpretation as antidunes is not straightforward for DBs in PDC deposits.

Cross-stratified dune bedforms produced by pyroclastic density currents during the August 2006 eruption at Tungurahua volcano have been described. Four types of dune bedforms have been qualitatively defined - elongate, transverse, lunate, and two-dimensional - and quantitatively distinguished based on more than 300 measurements of shape characteristics. 
The development of each type of dune bedforms varies spatially and records different conditions. In proximal zones, elongate dune bedforms correspond to a separate sedimentary environment in the proximal areas, dominated by the interaction between granular based and tractional flow boundaries. There, flows were topographically unconfined and the deposits are the record of the mixed and successive influence of dense pyroclastic flows (lensmBLA-facies) and dilute PDCs ( $x s b A L$ - and $m b A L$-facies), indicating currents with a strong capacity and competence. The stoss-aggrading, lensoidal layers of lensmBLA-facies of these dune bedforms are not interpreted as "chute-and-pool" or antidune structures. They likely result from stoss-side blocking of material transported as bedload. Elongate patterns are absent in the distal record, where dense pyroclastic flows were confined to valley thalwegs and only dilute PDCs acted on sedimentation.

Transverse and lunate DBs are found in the ash bodies of the distal environment, where only dilute PDCs overflowed and deposited. These zones are dominated by direct fallout and tractional flow boundary processes, with dilute PDCs having a significant deposition rate and with particle concentrations above the saturated transport conditions. These zones probably record hydraulic jumps responsible for a sudden deceleration of the flows (Douillet et al. 2013). Transverse dune bedforms grew at the onset of the deposition zones as a result of highly depositional currents with low competence. Lunate dune bedforms are related to currents whose sedimentation rates are related to the thickness of the dune bedform: the thicker the obstacle, the more stoss-face aggradation it experiences. Alternatively, they might form in the presence of two current directions. Two dimensional dune bedforms outcrop on the edges of deposition zones and where the deposition areas dipped against flow direction. In both cases, significant lateral spreading of the PDCs occurred.

We do not interpret the transverse, lunate and twodimensional dune bedforms as antidunes. Rather, these three types of dune bedforms are the expression of highly depositional dynamics and seem to be an extreme case of climbing dune. A low bedload transport component and major direct sedimentation from suspended load during waning phases of the currents led to upstream migration of the crests under subcritical flow conditions. We suggest the term "regressive climbing dunes" for bedforms produced by such a process, which might occur in all types of particulate density currents.

Acknowledgments Drs. Manville, Sulpizio, and Cioni are acknowledged for valuable reviews; Prof. Andreotti for discussion; our colleagues from Instituto Geofisico, Quito, for discussion, information, and help during field work; Yan Lavallée for editing the manuscript; and Jean-Rémi Dujardin for editing the photographs. We are indebted to the following (partial) funding sources: Alsatian grant BOUSSOLE (GAD); the grant THESIS from the Elite Network of Bavaria (GAD); the Deutsche Forschungsgemeinschaft grant KU2689/2-1 (GAD, UK), the Deutsche Forschungsgemeinschaft grant LA 2651/1-1 (UK, YL); a Research Professorship (LMUexcellent) of the Bundesexzellenzinitiative (DBD); an advanced grant from the European Research Council-EVOKES (DBD). GAD and DAP thank the bomberos from Baños and Patate for rescue during fieldwork.

Open Access This article is distributed under the terms of the Creative Commons Attribution License which permits any use, distribution, and reproduction in any medium, provided the original author(s) and the source are credited.

\section{References}

Alexander J (2008) Bedforms in Froude-supercritical flow. Marine and River Dune Dynamics, Leeds, pp 1-5, 1-3 April 2008

Alexander J, Bridge JS, Cheel RJ, Leclair S (2001) Bedforms and associated sedimentary structures formed under supercritical water flows over aggrading sand beds. Sedimentology 48:133-152

Allen JRL (1970) A quantitative model of climbing ripples and their cross laminated deposits. Sedimentology 14:5-26

Allen JRL (1982) Sedimentary structures. Their character and physical basis. Elsevier, Amsterdam, p 663

Anderson RS (1990) Eolian ripples as examples of self-organization in geomorphological systems. Earth Sci Rev 29:77-96

Andrews B, Manga M (2012) Experimental study of turbulence, sedimentation, and coignimbrite mass partitioning in dilute pyroclastic density currents. J Volcanol Geotherm Res 225-226:30-44

Arnott RWC, Hand BM (1989) Bedforms, primary structures and grain fabric in the presence of suspended sediment rain. J Sed Res 59:1062-1069

Ashley GM, Southard JB, Boothroyd JC (1982) Deposition of climbingripple beds: a flume simulation. Sedimentology 29:67-79

Brand BD, Clarke AB (2009) The architecture, eruptive history, and evolution of the Table Rock Complex, Oregon: from a Surtseyan to an energetic maar eruption. J Volcanol Geotherm Res 180:203-224

Brand BD, Clarke AB (2012) An unusually energetic basaltic phreatomagmatic eruption: using deposit characteristics to constrain dilute pyroclastic density current dynamics. J Volcanol Geotherm Res 243-244:81-90

Brand BD, White CM (2007) Origin and stratigraphy of phreatomagmatic deposits at the Pleistocene Sinker Butte Volcano, Western Snake River Plain, Idaho. J Volcanol Geotherm Res 160:319-339

Brand BD, Clarke AB, Semken S (2009) Eruptive conditions and depositional processes of Narbona Pass Maar volcano, Navajo volcanic field, Navajo Nation, New Mexico (USA). Bull Volcanol 71:49-77

Branney MJ, Kokelaar P (1997) Giant bed from a sustained catastrophic density current flowing over topography: Acatlán ignimbrite, Mexico. Geology 25(2):115-118

Branney MJ, Kokelaar P (2002) Pyroclastic density currents and the sedimentation of ignimbrites. Geological Society Memoir no. 27. viii +143 pages

Bridge JS, Demicco RV (2008) Earth surface processes, landforms and sediment deposits. Cambridge: Cambridge University Press. $815 \mathrm{p}$. ISBN-10:0-521-85780-5

Brown RJ, Branney MJ (2004) Bypassing and diachronous deposition from density currents: evidence from a giant regressive bed form in the Poris ignimbrite, Tenerife, Canary Islands. Geology 32:445-448

Burgisser A, Bergantz GV (2002) Reconciling pyroclastic flow and surge: the multiphase physics of pyroclastic density currents. Earth Planet Sci Lett 202:405-418

Cagnoli B, Ulrich TJ (2001) Ground penetrating radar images of unexposed climbing dune-forms in the Ubehebe hydrovolcanic field (Death Valley, California). J Volcanol Geotherm Res 109: 279-298 
Carey SN (1991) Transport and deposition of tephra by pyroclastic flows and surges. In: Fisher, RV, Smith GA (eds). Sedimentation in volcanic settings. SEPM Special Publication No 45:39-57

Charland A, Lajoie J (1989) Characteristics of pyroclastic deposits at the margin of Fond Canonville, Martinique, and implications for the transport of the 1902 nuées ardentes of Mt. Pelée. J Volcanol Geotherm Res 38:97-112

Cheel RJ (1990) Horizontal lamination and the sequence of bed phases and stratification under upperflow-regime conditions. Sedimentology 37:517-529

Cole PD (1991) Migration direction of sand wave structures in pyroclastic-surge deposits: implications for depositional processes. Geology 19:1108-1111

Collela A, Hiscott RN (1997) Pyroclastic surges of the Pleistocene Monte Guardia sequence (Lipari Island, Italy): depositional processes. Sedimentology 44:47-66

Cooke R, Warren A, Goudie A (1993) Desert geomorphology. UCL Press, London, p 526

Crowe BM, Fisher RV (1973) Sedimentary structures in base-surge deposits with special reference to cross-bedding, Ubehebe Craters, Death Valley, California. Geol Soc Am Bull 84:663-682

Dellino P, Isaia R, Veneruso M (2004) Turbulent boundary layer shear flows as an approximation of base surge at Campi Flegrei (Southern Italy). J Volcanol Geotherm Res 133:211-228

Doronzo DM (2012) Two new end members of pyroclastic density currents: forced convection-dominated and inertia-dominated. J Volcanol Geotherm Res 219-220:87-91

Douillet GA, Tsang-Hin-Sun E, Kueppers U, Letort J, Pacheco DA, Goldstein F, Von Aulock F, Lavallée Y, Hanson JB, Bustillos J, Robin C, Ramón P, Hall M, Dingwel DB (2013) Sedimentology and geomorphology of the deposits from the August 2006 pyroclastic density currents at Tungurahua volcano, Ecuador. Bull Volcanol 75:765. doi 10.1007/s00445-013-0765-7

Druitt TH (1992) Emplacement of the 18 May 1980 lateral blast deposit ENE of Mount St. Helens, Washington. Bull Volcanol 54:554-572

Druitt TH (1996) Pyroclastic density currents. In: Gilbert JS, Sparks RSJ (eds) The physics of explosive volcanic eruptions, vol 145. Geological Society, London, pp 145-182

Duller RA, Mountney NP, Russell AJ (2007) Architectural analysis of a volcaniclastic Jo" Kulhlaup deposit, Southern Iceland: sedimentary evidence for supercritical flow. Sedimentology 55:939-964

Eychenne J, Lepennec JL, Troncoso L, Gouhier M, Nedelec JM (2012) Causes and consequences of bimodal grain-size distribution of tephra fall deposited during the August 2006 Tungurahua eruption (Ecuador). Bull Volcanol 74(1):187-205

Fisher RV (1977) Erosion by volcanic base-surge density currents: U-shaped channels. Geological Society of America Bulletin 88(9):1287-1297

Fisher RV (1990) Transport and deposition of a pyroclastic surge across an area of high relief: the 18 May 1980 eruption of Mount St. Helens, Washington. Geol Soc Am Bull 102:1038-1054

Fisher RV, Waters AC (1969) Bed forms in base surge deposits: lunar implications. Science 165:1349-1352

Fisher RV, Waters AC (1970) Base surge bed forms in Maar volcanoes. Am J Sci 268:157-180

Fisher RV, Schmincke HU, Van Bogaard P (1983) Origin and emplacement of a pyroclastic flow and surge unit at Laacher See, Germany. J Volcanol Geotherm Res 17:375-392

Gençalioğlu-Kuşcu G, Atilla C, Cas RAF, Kușcu İ (2007) Base surge deposits, eruption history, and depositional processes of a wet phreatomagmatic volcano in Central Anatolia (Cora Maar). J Volcanol Geotherm Res 159:198-209

Ghienne JF, Girard F, Moreau J, Rubino JL (2010) Late Ordovician climbing-dune cross-stratification: a signature of outburst floods in proglacial outwash environments? Sedimentology 57(5):1175-1198
Gianneti B, Luongo G (1994) Trachyandesite scoria-flow and associated trachyte pyroclastic flow and surge at Roccamonfina Volcano (Roman Region, Italy). J Volcanol Geotherm Res 59:313-334

Girard F, Ghienne JF, Rubino JL (2012) Occurrence of hyperpycnal flows and hybride vent beds related to glacial outburst events in a Late Ordovician proglacial delta (Murzuq basin, SW Libya). J Sed Res 82:688-708

Guyon E, Hulin JP, Petit L (2001) Hydrodynamique physique. Edition CNRS. ISBN-10:2-86883-502-3

Hall ML, Robin C, Beate B, Mothes P, Monzier M (1999) Tungurahua Volcano, Ecuador: structure, eruptive history and hazards. J Volcanol Geotherm Res 91(1):1-21

Hall ML, Samaniego P, Le Pennec JL, Johnson JB (2008) Ecuadorian Andes volcanism: a review of Late Pliocene to present activity. J Volcanol Geotherm Res 176(1):1-6

Hand BM (1969) Antidunes as trochoidal waves. J Sediment Petrol 39: 1302-1309

Hand BM (1974) Supercritical flow in density currents. J Sed Petr 44(3): 637-648

Hand BM, Middleton GV, Skipper K (1972) "Antidune crossstratification in a turbidite sequence, Cloridome Formation, Gaspé, Quebec. By Skipper (1971) Sedimentology" discussion. Sedimentology 18(1-2):135-138

Higgs R (2011) 'Hummocky cross-stratification-like structures in deepsea turbidites: Upper Cretaceous basque basins (Western Pyrénées, France). By Mulder et al. (2009), Sedimentology' Discussion. Sedimentology 58:566-570

Hoblitt RP, Dan Miller C, Vallance JM (1981) Origin and stratigraphy of the deposits produced by the May 18 directed blast. In: Lipman PW, Mullineaux DR (eds) The 1980 eruptions of Mount St. Helens, Washington, USGS Prof. Papers 1250

Kelfoun K, Samaniego P, Palacios P, Barba D (2009) Testing the suitability of frictional behaviour for pyroclastic flow simulation by comparison with a well-constrained eruption at Tungurahua volcano (Ecuador). Bull Volcanol 71(9):1057-1075

Kieffer SW, Sturtevant B (1988) Erosional furrows formed during the lateral blast at Mount St. Helens, May 18, 1980. J Geophys Res 93(B12):14793-14816

Kubo Y, Nakajima T (2002) Laboratory experiments and numerical simulation of sediment-wave formation by turbidity currents. Mar Geol 192:105-121

Lang J, Winsemann J (2013) Lateral and vertical facies relationships of bedforms deposited by aggrading supercritical flows: from cyclic steps to humpback dunes. Sediment Geol 296:36-54

Le Pennec JL, Jaya D, Samaniego P, Ramón P, Yánez SM, Egred J, van der Plicht J (2008) The AD 1300-1700 eruptive periods at Tungurahua volcano, Ecuador, revealed by historical narratives, stratigraphy and radiocarbon dating. J Volcanol Geotherm Res 176:70-81

Lorenz RD, Claudin P, Andreotti B, Radebaugh J, Tokano T (2010) A $3 \mathrm{~km}$ atmospheric boundary layer on Titan indicated by dune spacing and Huygens data. Icarus 205:719

Mattson PH, Alvarez W (1973) Base surge deposits in Pleistocene volcanic ash near Rome. Bull Volcanol 37(4):553-572

Moore JG (1967) Base surge in recent volcanic eruptions. Bull Volcanol 30(1):337-363

Moore JG, Nakamura K, Alcaraz A (1966) The 1965 eruption of Taal Volcano. Science 151:955-960

Mulder T, Razin P, Faugeres JC (2009) Hummocky crossstratification-like structures in deep-sea turbidites: Upper Cretaceous basque basins (Western Pyrénées, France). Sedimentology $56: 997-1015$

Nakajima T, Satoh M (2001) The formation of large mudwaves by turbidity currents on the levees of the Toyama deep-sea channel, Japan Sea. Sedimentology 49:435-463

Nemoto Y, Yoshida S (2009) Nested architecture of pyroclastic bedforms generated by a single flow event, Outcrop examples from the Izu 
volcanic islands. American Geophysical Union, Japan, Fall Meeting 2009, abstract \#V23C-2078

Ponce JJ, Carmona N (2011) Coarse-grained sediment waves in hyperpycnal clinoform systems, Miocene of the Austral foreland basin, Argentina. Geology 39:763-766

Prave AR (1990) Clarification on some misconceptions about antidune geometry and flow character. Sedimentology 37: $1049-1052$

Richards AF (1959) Geology of the Islas Revillagigedo, Mexico. 1. Birth and development of Volcano Bárcena, Isla San Benedicto. Bull Volcanol 22(1):73-123

Rowley PD, MacLeod NS, Kuntz MA, Kaplan AM (1985) Proximal bedded deposits related to pyroclastic flows of May 18, 1980, Mount St. Helens, Washington. Geol Soc Am Bull 96(11):13731388

Rubin DM (2010) A unifying model of planform straightness of ripples and dunes in air and water American Geophysical Union, Fall Meeting 2010, abstract \#EP43F-07

Samaniego P, Le Pennec JL, Robin C, Hidalgo S (2011) Petrological analysis of the pre-eruptive magmatic process prior to the 2006 explosive eruptions at Tungurahua volcano (Ecuador). J Volcanol Geotherm Res 199(1-2):69-84

Schmincke HU, Fisher RV, Waters AC (1973) Antidune and chute-andpool structures in the base surge deposits of the Laacher See area, Germany. Sedimentology 20:553-574

Sigurdsson H, Carey SN, Fisher RV (1987) The 1982 eruption of E1 Chichon volcano, Mexico (3): physical properties of pyroclastic surges. Bull Volcanol 49:467-488

Simons DB, Richardson EV, Haushild, WL (1963) Some effects of fine sediment on flow phenomena. U.S. Geol Surv Water Supply Pap 1498G-47

Sohn YK (1997) On traction carpet sedimentation. J Sed Res 67(3):502509

Sohn YK, Chough SK (1989) Depositional processes of the Suwolbong tuff ring, Cheju Island (Korea). Sedimentology 36:837-855

Sparks RSJ (1976) Grain size variations in ignimbrites and implications for the transport of pyroclastic flows. Sedimentology $23: 147-188$

Spinewine B, Octavio E, Sequeiros OE, García MH, Beaubouef RT, Sun T, Savoye B, Parker G (2009) Experiments on wedge-shaped deep sea sedimentary deposits in minibasins and/or on channel levees emplaced by turbidity currents. Part II. Morphodynamic evolution of the wedge and of the associated bedforms. J Sed Res 79(8):608628

Sulpizio R, Dellino P (2008) Sedimentology, depositional mechanisms and pulsating behaviour of pyroclastic density currents. In: Gottsman J, Marti J (eds). Calderas volcanism: analysis, modelling and response. Devel Volcanol 10:57-96
Sulpizio R, Mele D, Dellino P, La Volpe L (2007) Deposits and physical properties of pyroclastic density currents during complex Subplinian eruptions: the AD 472 (Pollena) eruption of Somma-Vesuvius, Italy. Sedimentology 54:607-635

Sulpizio R, De Rosa R, Donato P (2008) The influence of variable topography on the depositional behaviour of pyroclastic density currents: the examples of the Upper Pollara eruption (Salina Island, southern Italy). J Volcanol Geotherm Res 175(3):367-385

Sulpizio R, Bonasia R, Dellino P, Mele D, Di Vito MA, La Volpe L (2010) The pomici di avellino eruption of somma-vesuvius (3.9 ka BP). Part II: Sedimentology and physical volcanology of pyroclastic density current deposits. Bull Volcanol 72(5):559-577

Sumner EJ, Amy LA, Talling PJ (2008) Deposit structure and processes of sand deposition from decelerating sediment suspensions. J Sed Res 78:529-547

Suthren RJ (1985) Facies analysis of volcaniclastic sediments: a review. Geol Soc London Spec Publ 18(1):123-146. doi:10.1144/GSL.SP. 1985.018.01.07

Tanner WF (1967) Ripple mark indices and their uses. Sedimentology 9: $89-104$

Valentine GA (1987) Stratified flow in pyroclastic surges. Bull Volcanol 49:616-630

Valentine GA, Giannetti B (1995) Single pyroclastic beds deposited by simultaneous fallout and surge processes: Roccamonfina volcano, Italy. J Volcanol Geotherm Res 64:129-137

Vasquez JA, Ort MH (2006) Facies variation of eruption units produced by the passage of single pyroclastic surge currents, Hopi Buttes volcanic field, USA. J Volcanol Geotherm Res 154:222-236

Walker GPL (1984) Characteristics of dune-bedded pyroclastic surge bedsets. J Volcanol Geotherm Res 20(3-4):281-296

Walker GPL, Wilson CJN, Froggatt PC (1981) An ignimbrite veneer deposit: the trail of a pyroclastic flow. J Volcanol Geotherm Res 9:409-421

Waters A, Fisher RV (1971) Base surges and their deposits: Capelinhos and Taal volcanoes. J Geophys Res 76:5596-5614

Wilson CJN, Hildreth V (1998) Hybrid fall deposits in the Bishop Tuff, California: a novel pyroclastic depositional mechanism. Geology 26:7-10

Wohletz KH (1998) Pyroclastic surges and compressible two-phase flow. In: Freundt A, Rosi M (eds) From magma to tephra: modelling physical processes of explosive volcanic eruptions. Elsevier, Amsterdam, pp 247-311

Wohletz KH, Sheridan MF (1979) A model of pyroclastic surge. Geological Society of America 180:177-194

Wynn RB, Stow DAV (2002) Classification and characterisation of deepwater sediment waves. Mar Geol 192:7-22

Yokoyama S, Tokunaga T (1978) Base-surge deposits of Mukaiyama Volcano, Nii-jima, Izu Islands. Bull Volcanol Soc Jpn 23:249-262 